\title{
ICT-based solution approach for collaborative delivery of customized products
}

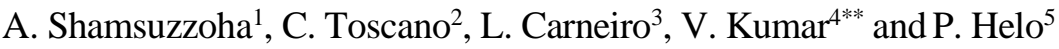 \\ ${ }^{1}$ Sultan Qaboos University, Muscat, Oman \\ Email: ahsh@squ.edu.om \\ ${ }^{2}$ INESC TEC, Porto, Portugal, Email: ctoscano@inescporto.pt \\ ${ }^{3}$ Department of Manufacturing Systems Engineering, INESC Porto, Portugal \\ Email: luis.carneiro@inescporto.pt \\ ${ }^{4 * *}$ Bristol Business School, University of the West of England, Bristol, UK \\ Email: Vikas.Kumar@uwe.ac.uk \\ ${ }^{5}$ Department of Production, University of Vasa, Finland \\ Email:phelo@uwasa.fi \\ ** Corresponding author
}

** Corresponding Author Details

Dr. Vikas Kumar

Bristol Business School,

University of the West of England,

Coldharbour Lane, Bristol, BS16 1QY, UK

Email: Vikas.Kumar@uwe.ac.uk

Tel: +44 (0) 117 32-83466; Fax: +44 (0)117 3282810 


\title{
ICT-based solution approach for collaborative delivery of customized products
}

\begin{abstract}
Growing interest on business collaboration motivates today's industries, especially small and medium enterprises (SMEs) to establish and manage dynamic and non-hierarchical business networks to respond to market opportunities with added business benefits. This business environment requires concurrent work and real time information sharing between key business partners in order to design and develop customized products. The use of traditional communication media such as e-mail, phone and fax are not satisfactory to get real-time information and are time consuming and most often ineffective. In such environments, an ICT (Information and Communication Technology)/Web-based technology supports real-time information sharing among networked SMEs for the collaborative design and manufacturing of customized products. This paper proposes an innovative ICT platform supporting SMEs collaboration, through Web and the Internet of Things (IoT) technologies, which follows the Net-Challenge conceptual approach and methodological guidelines for SMEs to form and operate virtual organizations (VO) for the collaborative development and delivery of customized products. The ICT Platform was assessed in three different industry domains, namely the textile \& apparel, the footwear and the machine tools respectively. This ICT solution promotes collaboration, with substantial advantages for SMEs including the reduction of costs and delivery time and improvement of the innovation potential.
\end{abstract}

Keywords: Collaborative business network, ICT, SMEs, virtual organization (VO), production planning, operational monitoring, Internet of Things, event management.

\section{$1 \quad$ Introduction}

In order to survive in today's competitive business world, companies, especially manufacturing companies need to integrate their costly resources and competencies as much as possible. Such integration enables them to respond to growing demands for customized products quite comfortably. Collaborative product design and development nowadays attracts more attention among companies, especially among SMEs ( $\mathrm{Li}$ et al. 2009). The prime concern to promote collaborative business is to design and develop cost effective and innovative collaborative product. The concept of collaborative product design and development process for SMEs can be described as an environment, where the generation of the product concept and its engineering, production planning and scheduling, operational monitoring and abnormal situations (events) management are done concurrently among the collaborative partner organizations (Ming et al., 2008; Shamsuzzoha et al., 2013).

Before initiating the collaborative business, the broker company identified the possible business opportunity after rigorous market survey. The partners are selected based on predefined criterions before forming the collaborative network (Crispim and Pinho de Sousa, 2010; Carneiro et al., 2014). This network formation process can be expedited through the implementation of ICT-enabled platform. The design and development of ICT-based platform contributes not only to build collaborative business networks but it also supports real-time process monitoring and management of collaborative processes. Such real time process monitoring system enables partners to find out process bottlenecks if there are any and adopt necessary actions to eliminate or minimize them. 
Based on the above requirements this research work identified two research objectives, which are necessary to fulfil in order to establish an effective business network. The two research objectives are as follows:

(a) to design and develop an ICT-based platform to support establishing a collaborative business network with the objective to develop complex customized products.

(b) to implement an ICT-based communication framework to contribute to real time monitoring and management of collaborative business processes for mutual benefit

Several researches have been done in order to address ICT framework within business network. Buttol et al. (2012) implemented ICT and online services to support SMEs on a path of product eco-innovation within hierarchical business network. ICT requirements analysis for enterprise networks are extensively discussed by Afsarmanesh and Thamburaj (2012), where they proposed the common ICT platform and the tools to enhance the functionality effectiveness for coworking and co-innovation among the collaborative stakeholders. A case study has been presented by Iskanius and Kilpala (2006) to demonstrate the ICT implementation to build up the real-life digital business network consisting of a number of small and medium-sized enterprises (SMEs) operating in co-operation with one focal company.

In literature, several ICT-based platforms have been developed to support business collaboration but most of them deal with hierarchical business network (Hossain and Wigand, 2004). Most studies do not deal with non-hierarchical network (NHN), where collaborative partner companies with similar product portfolios and sizes form a business network, and enjoy equal rights and controlling power. Such NHN are generally formed by the SMEs, where scarcity of resources and real-time communication are important concerns (Carneiro et al, 2010; Kankaanpaa et al., 2010). This research therefore outlines an ICT-platform to support business collaboration within non-hierarchical network (NHN).

The application of ICT allows partners to execute both front-end and back-end business processes, thus improving the overall value chain efficiency (Wortmann and Szirbik, 2001; Camarinha-Matos, 2005). Business networking is not new and many companies are already practicing it to gain competitiveness. However, ICT, and especially business network applications, has now emerged as an enabler for business integration, both in vertical integration with customers and horizontal integration with competitors (Rabelo, 2008; Carneiro et al., 2013).

This study presents a development process of virtual organization that aims to gain competitive advantage through increasing cooperation and collaboration and visibility in its partners' processes. Such collaboration and visibility can be achieved through the ICT solutions as highlighted within the scope of this research. This ICT application provides collaboration in information sharing, operational cooperation and dynamic business configuration. Furthermore, ICT integrates physically distributed manufacturing companies and their customers to ensure timely and accurate information exchange among all the members of the business network.

The rest of the paper is organized as follows. Section 2 presents a review of the existing literature on business collaboration with respect to product design and development, while Section 3 describes the research methodology as adopted in this research. Section 4 highlights the role of ICT-based tools in developing collaborative product design and development. Section 5 introduces the concept of the Internet of Things and smart objects in the monitoring and management of collaborative business processes. In Section 6, an ICT web-based solution is presented in the scope of an overall methodology supporting the creation and operation of non-hierarchical business networks. The overall managerial 
implications of this research are illustrated in Section 7. This paper is concluded with future research directions in Section 8.

\section{Theoretical Framework}

\subsection{Business collaboration within manufacturing companies}

There is a growing recognition that collaborative business offers significant opportunities for manufacturing companies to create competitive advantages and achieve superior outcomes (Camarinha-Matos, 2009; Romero and Molina, 2014). In today's market place manufacturing companies are reducing their overall supply base and focusing on closer relationships with similar companies in order to achieve business benefits (Panetto et al., 2012; Doloreux and Shearmur, 2012; Ren et al., 2014). Consequently, companies are facing growing trend towards business collaboration. Therefore, companies also need to understand how they can create and deliver value in business-to-business relationships. The measurement of value creation in business relationships is a prerequisite for developing reliable and valid collaborative network (Hakansson, 2014). Using an alliance with a partner reflects the commitment and capacity of each partner to absorb the skills of the other.

In today's complex business environment, there has been unprecedented growth in corporate partnering and reliance on various forms of external collaboration (AarikkaStenroos et al., 2012; Ramanathan and Gunasaekaran, 2014). These various forms of temporary alliances take on many manufacturing companies, starting from research and development collaborations to equity joint ventures to collaborative manufacturing to complex co-productions arrangements (Forsgren and Johanson, 2014). Such collaborations can be named differently such as business community (Carneiro et al., 2010, Kankaanpaa et al., 2010), virtual organizations (Camarinha-Matos, 2009: Camarinha-Matos et al., 2009), collaboratine network organizations (Dutton, 2008; Romero and Molina, 2011), and industry cluster (Feser and Bergman, 2000). The objectives of such collaborations are generally same such as risk sharing, access to new markets and technologies, pooling complemntary skills and faster products to markets. Various diemensions, elements and benefits of business collaboration as discussed in the literature can be summarized as shown in Table 1.

Table 1: Various dimensions, elements and benefits of business collaboration

\begin{tabular}{|c|c|c|}
\hline Dimensions & Elements & Benefits \\
\hline $\begin{array}{l}\text { ICT framework for } \\
\text { collaborative business } \\
\text { (Barczak et al., 2007; } \\
\text { Almeida and Azevedo, } \\
\text { 2011; Afsarmanesh and } \\
\text { Thamburaj, 2012;Buttol et } \\
\text { al., 2012) }\end{array}$ & $\begin{array}{ll}\text { - Establishment of ICT } \\
\text { platform } \\
\text { - Develop cross enterprise } \\
\text { business architecture } \\
\text { - Design business network } \\
\text { - Integrate business process }\end{array}$ & $\begin{array}{l}\text { - Enhance busines networking } \\
\text { - Faster resource capture } \\
\text { - Build trust among partners } \\
\text { - Promote faster } \\
\text { - Eommunication } \\
\text { - Expand buisness networking }\end{array}$ \\
\hline $\begin{array}{l}\text { New Business } \\
\text { Methodology (Rabelo et al., } \\
\text { 2009, Carneiro et al., 2010; } \\
\text { 2013; Kankaanpaa et al., } \\
\text { 2010) }\end{array}$ & $\begin{array}{l}\text { - } \text { Virtual communication } \\
\text { - } \text { Collaborative buiness } \\
\text { processes } \\
\text { - Sharing valuable resources } \\
\text { - Customized product } \\
\text { development } \\
\text { - Plug and play business model }\end{array}$ & $\begin{array}{l}\text { Provide optimize networking } \\
\text { guidelines } \\
\text { - Better use of collaborative } \\
\text { assets } \\
\text { - New buisness opportunity } \\
\text { - Offer competitive business } \\
\text { environment }\end{array}$ \\
\hline Real-time information & - Ontime information sharing & - Advance probelm notification \\
\hline
\end{tabular}




\begin{tabular}{|c|c|c|}
\hline $\begin{array}{l}\text { integration (Park and } \\
\text { Favrel, 1999; Fan et al., } \\
\text { 2002; Gunsaekaran and } \\
\text { Ngai, 2009; Peng et al., } \\
\text { 2014) }\end{array}$ & $\begin{array}{l}\text { - Transparency of information } \\
\text { - Notifying error meassage }\end{array}$ & $\begin{array}{l}\text { - Quick response to problems } \\
\text { - Establishment trust among } \\
\text { partners }\end{array}$ \\
\hline $\begin{array}{l}\text { Syncronized process } \\
\text { planning and control (Toye } \\
\text { et al., 1993; Chryssolouris } \\
\text { et al., 2007; Lee et al., } \\
\text { 2012; Almeida et al., 2013) }\end{array}$ & $\begin{array}{l}\text { - Collaborative production } \\
\text { processes } \\
\text { - Synchrinized process } \\
\text { planning and routings } \\
\text { - Interoperable process } \\
\text { integration } \\
\end{array}$ & $\begin{array}{l}\text { - Optimize process planning } \\
\text { - Reduce production lead time } \\
\text { - Improve operational service } \\
\text { level } \\
\text { - Bring process integrity }\end{array}$ \\
\hline $\begin{array}{l}\text { Smart process monitoring } \\
\text { (Phaithoonbuathong etal., } \\
\text { 2010; Shamsuzzoha et al., } \\
\text { 2013; Harmon, 2015; } \\
\text { Ferreira et al., 2015) }\end{array}$ & $\begin{array}{l}\text { - Identifying process } \\
\text { abnormalities } \\
\text { - Coordinate process execution } \\
\text { - Real-time process status } \\
\text { - Plan to avoid risks and events }\end{array}$ & $\begin{array}{l}\text { - Avoid process bottlenecks } \\
\text { - Uphold smart process } \\
\text { management } \\
\text { - Reduce process interuption } \\
\text { - Avoid or minize process risks }\end{array}$ \\
\hline $\begin{array}{l}\text { Partner management } \\
\text { (Camarinha-Matos, 2005; } \\
\text { Camarinha-Matos et al., } \\
\text { 2009; Rabelo et al., 2009; } \\
\text { Romero and Molina, 2011) }\end{array}$ & $\begin{array}{l}\text { - Design partners criterions } \\
\text { - Invite potential partners } \\
\text { - Selection of partner } \\
\text { - Make collaboration } \\
\text { agreement }\end{array}$ & $\begin{array}{l}\text { - Promote network's benefits } \\
\text { - Attracts best partners } \\
\text { - Increase partners cohesion } \\
\text { - Decentralize partners skills } \\
\text { - } \text { and expertises } \\
\text { - Promote trust developement }\end{array}$ \\
\hline
\end{tabular}

\subsection{Collaborative Product Development within Virtual Business Network}

Advances in technology in the last decade have influenced changes in the design and engineering of products and accompanied services on a global scale (Cavalieri and Pezzotta, 2012; Valilai et al., 2013). Development of lean and collaborative product approaches are increasingly adopted by the manufacturing companies and seen as the core of product life cycle management (Panchal and Fathianathan, 2008; Wu, 2012; Evanschitzky et al., 2012). These trends have created the need for new business model where individual companies with limited resources and skills can come forward to form and execute a collaborative business environment (Schleimer and Shulman, 2011). Within this business environment, the partner companies must realize that product design decisions are not made in isolation and there are likely to be wider implications. It would appear that each partner needs to tackle problems that are aligned to business drivers or initiatives, such as repeatability to manufacture, design for after sales service and support for lean product development.

The development of product-service systems raises interesting opportunities for the manufacturing companies to meet customer needs (Isaksson et al. 2009; Gebauer et al., 2010). In search for an increased customer value, a long-term improved return on investment and a more stable cash flow management combined with optimal resource utilization is required. Thus manufacturing companies are moving towards collaborative product development scenario (He and Lai, 2012). Such a collaborative business scenario or model shifts in business conditions relates to the companies' traditional and future products, and are likely to discover many opportunities for their products, processes and business. Effective collaborative product development contributes to customer satisfaction in myriad ways, including responsiveness to customer needs, cost management, innovation and speed and quality of products and services (Fielding et al., 2014). The bottom line is that the shift in 
business model has an impact on the way the manufacturing companies are developing products or services or both products-services.

The concept of developing collaborative product is highly applicable within the SMEs. In collaboration, large amounts of product information are exchanged between the network partners in order to support the quality of product design and development. Collaborative business can be defined as the environment where the partners form a virtual organization based on multi-criteria approach (Verdecho et al., 2012) and operate for achieving specific benefits in the form of sharing knowledge and experience, resources, potential risks, responsibilities, etc. (Camarinha-Matos, 2005; Wnag and Zhang, 2008). Collaboration creates more value adding activities in the complex value chain and business ecosystems globally (de Campos, 2007). It offers new business opportunities and provides lean manufacturing that may result in quality products. The types of collaboration can be in different formats such as joint ventures, strategic alliances, industrial districts, consortium, social networks and others (Almeida and Azevedo, 2011).

\subsection{Application of ICT-Enabled Platform in Collaborative Product Design and Development}

Globalization and technological advances are motivating manufacturing companies to extend the boundaries of their product development activities from traditional collocated settings to dispersed or distributed virtual settings (McDonough et al., 2001; Malhotra and Majchrzak, 2004; Buyukozkan and Arsenyan, 2012). Such virtual settings have wide array of ICTs at their disposal, which promotes virtual collaboration in various forms and formats (Montoya et al., 2009; Ebrahim et al., 2010). The development of ICT and in particular the Internet and other network technologies has allowed new possibilities for companies to manage their both front-end and back-end product development processes. Both ICT and Internet can be used to gain global visibility across their extended network of collaborative partners and help them to respond quickly to a range of variables, from customer demand to resource shortages (Chryssolouris et al., 2009).

Rapid development of ICT/Web-based technologies have revolutionized the complex product development. This complexity involves the integration of distributed resources and the product related information system (Hao et al., 2006). In order to manage such complexity and to be innovative, manufacturing firms are attempting to find ways to improve their flexibility and responsiveness and in turn competitiveness through implementation of ICT in their operations strategy, methods and techniques (Gunasekaran and Ngai, 2004; Nami and Tavangarian, 2007; Pouly and Huber, 2009; Durugbo and Ridel, 2013). ICT also enhances the establishment of a collaborative environment among companies through integrating diverse information systems that can enable the creation of virtual organizations (Young, 2008; Rabelo et al. 2009; Nucciarelli and Gastaldi, 2009; Cheikhrouhou et al., 2011). This collaboration contributes competencies among partner organizations to effectively and efficiently share their knowledge and collaborate with each other to compete in a global market. The inherent complexities of product design and engineering activities generally require the cooperation and coordination from multidisciplinary design teams in order to develop the quality and cost effective product. To cope with frequently changing business environment, enterprises should integrate value chains. It is very important to have an efficient collaborative environment, where the multiple design and engineering tasks of a product and sharing product information can be mediated among individual partner organizations (Alarcon et al., 2009; Lee et al., 2009). This environment should have an automated and real-time information flow strategy among the collaborative business partners (Chituc et al., 2009; Loss et al., 2010; Chan et al., 2012). The Internet and ICT/Web-based 
technologies can be adopted by the manufacturing firms, especially in collaborative product development environments to create information availability that is accessible, cost-effective and useful for broad range of applications (Huang and Mak, 1999; Shen, 2000; Shen and Wang, 2002; Renner, 2002).

Business collaboration in the form of e-collaboration with active support from ICT or web-enabled technology allows the integration of business processes and the sharing of information among collaborative organizations that ultimately contributes organizations to gain competitive advantages (Camarinha-Matos et al. 2009; Chan et al., 2012; Choudhary et al., 2013). To improve product creation at the present level of market competition, manufacturers have to continually utilize computer and network technology to develop enterprise information systems and adopt business network with the view to reduce development cost (Levy and Powell, 2000). Information technology has the potential to revolutionize the way a small business adapts to new business opportunities through lowering transaction costs, reduced marketing and communication costs and global expansion and improved business-to-business networking (Johnston, 1998; Isenberg et al., 2011). This networking is crucial to small businesses and ICT-based technology enables SMEs to expand their networking and business opportunities onto a global stage with minimum capital investment (Li et al., 2005).

There have been many ICT platforms developed so far to support business collaboration with various requirements and specifications. For instance, Rabelo et al. (2006) presented an ICT infrastructure that allows a well-established group of organizations in the virtual organization breeding environment (VBE) to collaborate between each other as well as to manage this collaboration. Chituc et al. (2009) proposed an ICT-enabled collaborative interoperability framework to support seamless interoperability in a networked business environment. Iskanius et al (2009) highlighted an ICT-based solution deploying agent technology to integrate dispersed companies and customers to ensure that all the members of the network receive accurate and timely information. Carneiro et al. (2010) proposed an ICTbased dynamic framework to form and execute non-hierarchical business networks to assure competitiveness and sustainability. The ICT-enabled framework as presented in this paper highlights mainly the formation of virtual organization that supports not only non-hierarchical business collaboration among industries (mostly SMEs), but also help to develop true customized product known as 'one-of-a-kind' product. This framework is unique than previously developed frameworks with respect to their flexibly to apply, manage and retrieve the development and management of virtual organizations effectively and efficiently.

\section{Design/methodology/approach}

The methodology of this research can be divided into several sub-phases as follows:

(a) This study is based on a comprehensive literature review of past and recent developments in the area of business networking, collaborative product development within virtual business network, and implementation of ICT-enabled platform to design and develop collaborative product.

(b) Six case companies within three business networks namely: textile \& apparel, footwear, and machine tool industry were considered in this study and their business strategies and collaboration processes were analysed. In depth interviews were conducted with the case networks key personnel's as well as their business partners.

(c) The case studies were helpful to collect the requirements for the collaborative processes and to identify their needs in the area of ICT support tools. 
(d) From the need of collaborative processes and support tools, a conceptual ICT-enabled platform is designed and developed with the objective of creating and managing business networks to develop collaborative product.

(e) The developed conceptual ICT platform was implemented, refined and validated as a part of the case networks and their RTD partners.

\section{Role of ICT/Web-based technology for developing collaborative product for SMEs}

Continuous demands for the development of innovative and quality products are the critical issues of success for all companies, especially for SMEs whatever the country or size. However, it is risky to invest on new or innovative products for companies/SMEs, where the failure might result devastating for them. New, innovative and custom-tailored products also need large expenditures related with research and development, production tooling, market search and promotional activities, which is often out of capacities for a SME. In such business circumstances, SMEs are encouraged to form and operate required collaboration among them. During collaboration, a firm should consider the trade-offs of each, measure the business gain against the associated challenges and identify the organizational capabilities, structure and resource availability to manage such challenges (Pisano and Verganti, 2008).

The scope of collaborative product design and development is huge in terms of sharing knowledge and expertise, exchanging innovative ideas and utilization of valuable resources, among the partner organizations. The fundamental goal of collaborative product development is to map the value stream within the product lines (Chryssolouris et al., 2007; Peng et al. 2014). In order to cooperate with each other in their production lines, manufacturing firms form temporary consortiums known as virtual organizations (VO). A VO is formed and operated after identifying definite business opportunities and is dissolved when the opportunities are over. Before forming the $\mathrm{VO}$ a contractual agreement is signed among the partners that represent the detailed of investment, risk and profit sharing, individual responsibilities, etc.

In collaboration, the ICT-based technology plays an important role for establishing the communication, trust and real-time information update among the networked partners. The real-time information update can be defined as the information sharing among partner organizations instantly with the help of ICT or Web-based platform such as Internet (Campos, 2009). Such type of information update is related to the maintenance of collaborative business processes security. The information to be exchanged between partners is agreed upon separately with each partner. This also requires specific protocols before exchanging real-time information between partners. Based on the predefined protocols and access, right individual partner can get the necessary information. This real-time information exchange supports electronic maintenance, where the processes are monitored and managed over the Internet. In case of Internet failure, such kind of maintenance work is also disrupted until the Internet connection is restored.

This technology can be used to enhance knowledge exchange and can also be utilized as a source of providing new forms of value adding activities among the collaborative network (Benbya et al., 2004; de Berranger et al., 2004). Rapid advances in ICT-based technology has contributed to interlink the activities of companies into giant networks, make it possible to widely distributed companies to cooperate with each other through computer networks in the Internet. This internet technology not only change the traditional way as companies interact with each other but also changed dramatically the basis on which business is conducted (Cecily et al., 2011). 


\section{$5 \quad$ Internet of Things for monitoring collaborative business processes}

Business process tracking and tracing on real-time is a basic requirement for any collaborative network organization. This tracking requirement includes real-time status tracking such as the case of process monitoring to improve workflow, continuous inventory location tracking, and materials tracking to prevent left-ins during production execution. The demand for increased accuracy and timeliness of information about business processes motivates collaborative partners to understand their operational levels that lead to process optimization. The implementation of real time monitoring enables partner organization to better control and manage business processes that deals with products and resources, the environments or persons. In such business situation, sensory information increases the accuracy of real world checks and thus forms the foundation of event-driven management (Haller et al., 2009). Today's automated sensing devices offer a new and much finer granularity of information management that supports the easy discovery, communication and application of events across the business organizations (Bi et al., 2014).

The advancement of sensor-enabled technologies such as Internet of Things (IoT), smart objects, wireless technology, etc., play a critical role in monitoring and manage business processes in networked businesses. RFID (Radio-Frequency Identification) tags, actuators, mobile phones, wireless sensor network systems, near field communications (NFC), etc., can coexist in sensor networks to provide capabilities such autonomous and proactive behaviour, context awareness and collaborative communications. Sensor networks are organized as a set of sensing and acting nodes which communicate in a wireless multi-hop fashion (Atzori et al., 2010).

The IoT concept can be applied to automate the monitoring and management of collaborative business processes. Information periodically sent by smart objects in the context of activity execution may be exploited to inform any stakeholder in the process about recent issues in both ongoing and upcoming manufacturing processes. This can be in the form of measuring the progress of operational activities, informing about problems or bottlenecks during process execution, issue alarms and notifications, etc. Business process monitoring improves the overall efficiency of the partners companies that ultimately reduces costs and improves throughput. Implementation of IoT through smart objects makes it easy and costeffective to deploy predictive intelligence through manufacturing processes. This predictive intelligence can be extended to areas that were previously out of physical or economic reach.

The exploitation of the IoT in the form of smart objects can be addressed as depicted in Figure 1. Each sensor-based smart object is located in the physical environment affecting an individual process. Updated information regarding normal and abnormal conditions is transmitted in a proactive manner to higher level information processing elements. At this level, information is analysed, filtered and aggregated so that management tasks could be achieved. For example, conditions requiring user attention may be displayed in a web-based platform in the form of a 'Dashboard' or be individually sent to mobile devices in the form of text messages. In a collaborative business environment, smart objects are located in dispersed manufacturing locations, and information may be processed and displayed in a web-based platform and accessible to the stakeholders in the collaborative process in order to identify the level of alerts (high, low, medium), the status of activities in the collaborative process (machine break down, shortage of raw materials, etc.), faulty parts/components, etc. The partner responsible for a given process has real-time access to its status and can take the necessary actions or measures. 


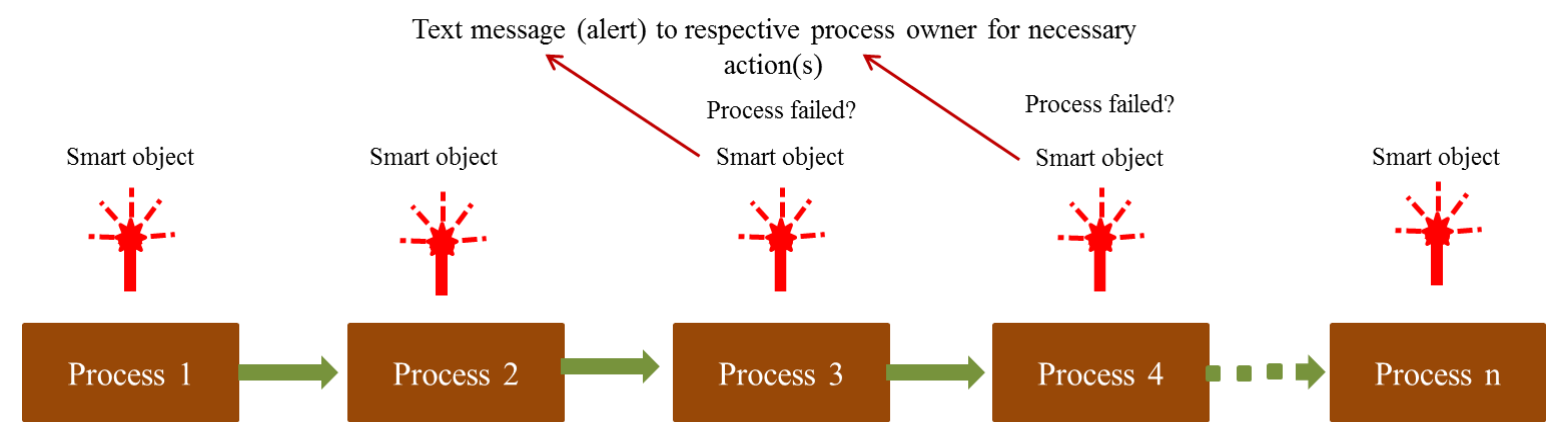

Figure 1: Conceptual model for collaborative business process monitoring using IoT (smart objects)

\section{Application of ICT/Web-based technology in business networks: a case example}

Today's product design and development processes are inherently complex, distributed and interdisciplinary. The increasing rate of complexities is forcing companies to be more and more collaborative for mutual understanding and achieving benefits. This collaborative environment enables the emergence of a new paradigm of collaborative design, engineering, and manufacturing of customized products. The sharing of knowledge in distributed collaborative design processes usually takes place in established partnerships only, where mutual trust exists and proper agreements among the partners have been set up (Pawlak et al., 2011). The collaboration within SMEs links a more rigid form of collaborative network, often termed as virtual organization that can be shorter or longer term depending on the nature of business potential.

The case example as presented in this study is taken from the results achieved in a European research project (Net-Challenge, http://www.netchallenge.org/), where the goal was to support the creation and management of non-hierarchical business networks where SMEs join competencies and resources to succeed on the global market in the design and manufacturing of complex products. This was accomplished by the definition of the NetChallenge Methodology, which defines the relevant concepts, high level activities and guidelines that support collaboration in non-hierarchical business networks, aiming at the development of high-variety and low-volume businesses, related with complex products design and manufacturing (Carneiro et al., 2010; Carneiro et al., 2013). This was later conveyed to and exploited on an ICT web-based platform, the Net-Challenge Platform, responsible for supporting most of the Net-Challenge proposed collaboration processes. Together, the Net-Challenge conceptual Framework and Platform were demonstrated in three case networks coming from specific industrial sectors: textile and apparel (in Portugal), footwear (in Italy) and machining tools (in Spain). The project consortium included a total of six pilot companies, two per each of the case networks that were selected among the key members of such networks. These companies played a key role in the requirements analysis, in the test and improvement of the solution and in the demonstration of the final results (Carneiro et al., 2010).

\subsection{Net-Challenge main concepts}


According to the Net-Challenge Framework, a Business Community (BC) is defined as a group of organizations, mainly SMEs, which are working in the same regional or sectoral business field, and where trust can be built and information and knowledge communication streamlined so as to facilitate the fast and efficient creation of business networks. An organization in the $\mathrm{BC}$, its Facilitator, is responsible to animate and promote networking in the community and to implement administrative tasks, as for example, support the evaluation and admission of new members, based on a pre-established regulation.

The exploitation of specific business opportunities is the key aim in a Business Community. Through the participation in the community's activities, as specified by the NetChallenge Methodology, members are expected to form Virtual Organizations (VO), sets of (legally) independent organizations that share resources and skills to respond to specific market opportunities, but that is not limited to a business alliance between those organisations. Virtual Organizations are temporary organisational forms that are created to respond to specific market opportunities and subsequently dissolved when the opportunity is satisfied (Camarinha-Matos et al., 2008:6). Two specific manufacturing scenarios are supported: Engineer-To-Order (ETO) and Customized-To-Order (CTO). In the ETO scenario, the main focus is the development of one-of-a-kind products. During its formation phase, customer requirements are captured, product specification is accomplished and planning specifies how this one unit or one instance of a large quantity of the conceived product will be manufactured in the subsequent operating phase. The CTO approach is used for customization scenarios, where the importance of defining a product platform is essential, product variants are created after configuring the product according to each customer needs and supports true customization. In both types of Virtual Organizations, the organization that identifies the business opportunity and is responsible for the formation of the VO is the VO Broker. Usually, he represents the customer and is responsible for coordinating all the formation, operation and dissolution phases among the partnership.

\subsection{Major requirements for the Net-Challenge ICT Platform}

The Net-Challenge Framework proposes a large number of collaboration processes both at the Business Community and Virtual Organization levels. Due to its inherent social nature, some of the collaboration activities between members in a community and partners in a Virtual Organization were proposed to be naturally supported by existing social networking ICT technology. Promoting networking and trust between Business Community members, and defining the strategy, business model and governance model of the community are examples of such collaboration activities that may be supported by information content sharing and document repository types of functionalities in an ICT platform. On the contrary, collaborative planning of the design and manufacturing activities between the members in a given Virtual Organization, and monitoring its execution along time and reacting to detected abnormal events are operational processes that deserve the development of specific decision support ICT tools. As such, the strategy was to select an existing ICT platform, providing a rich set of information and social media applications, and adapt and customize it to the specific Net-Challenge Framework requirements. Moreover, the chosen ICT platform should be open and support the development of specific functionality. Its selection was guided by the following major requirements:

- Explicit support of the major organizational entities: organizations (modelling the SMEs), community as a set of organizations, collaborative projects as a specific group of organizations in a given community. Organizations are represented by persons. As dictated by the Framework, information created in a collaboration project can only be 
shared by the correspondent partnership, but information created in the corresponding community is accessible in all the collaborative projects created in that community.

- Explicit support of independent communities, so that no information is shared between members in separate communities.

- Implementation of functionality commonly provided by Content Management Systems (creation and sharing of information, creation and sharing of multimedia document libraries, navigation along published information, etc.).

- Open and modular codebase, so that specific developments can be added and easily integrated. Additionally, all the applications provided by the ICT platform should be modelled as components and support different ways of laying them in the different workspaces. Different communities may have different user interfaces, and EngineerTo-Order and Customized-To-Order scenarios naturally demand different user interfaces.

- Explicit support of private and public areas in the platform. Communities and collaboration projects need to expose information to the public (in the Internet), in order, for example, to publicize its existence and capture new members and/or partners. Furthermore, registered organizations and their representatives may need private areas where they store private information.

\subsection{Net-Challenge ICT Platform high-level system architecture}

Figure 2 identifies the main modules comprising the Net-Challenge ICT Platform. The top four modules support the formation and operation of virtual organizations (in the up following subsections, the term Collaborative Project is used as synonym to the term Virtual Organization) and implement the most critical collaboration processes defined by the NetChallenge Framework: searching in the community for the partnership that implements the required technical capabilities and have the adequate resources; collaborative specification of the product concept (ETO scenario) or of the product platform (CTO scenario); collaborative planning of the design, manufacturing and logistics activities required by the partnership to deliver the product to customer; and monitoring and reacting to abnormal conditions in the execution of the planned activities.

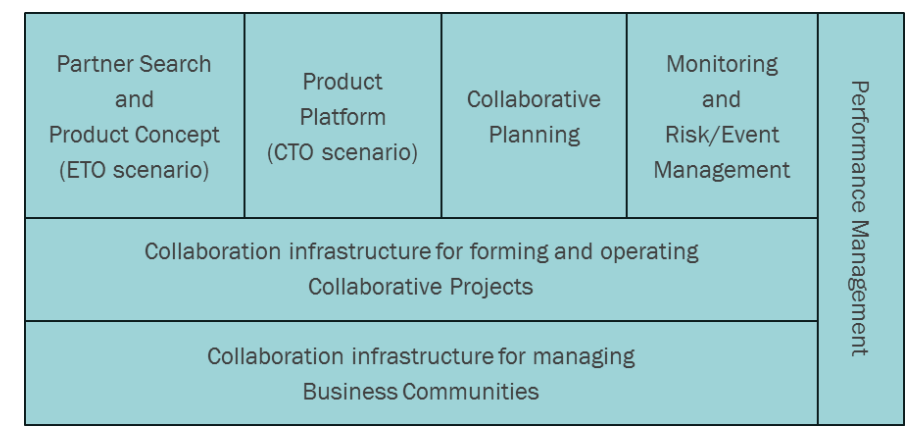

Figure 2: Main modules comprising the Net-Challenge ICT Platform

The collaboration infrastructure for collaborative projects (virtual organizations) (Figure 3) provides the workspace, making available all the above decision support tools in the support of forming and operating a given collaborative project. Additionally, a document repository and a wiki-based sub-subsystem are available to support the sharing of documents 
(contracts, non-disclosure agreements, and engineering designs) between the partners. The buttons in the area pointed by the arrow in Figure 3 activates a specific set of tab windows in the area below, allowing the User to get the details of the partnership defined so far (Partnership button) and to participate in the Form, Operate, and Dissolve phases of the collaborative project (Form, Operate and Dissolve buttons). Section 6.5 onwards describes these activities. In order to "guide" the user, the small boxes above the buttons specify the whole process and the current activity being achieved by the members: in the example illustrated in Figure 3, members are participating in the definition of the project's aggregate plan.

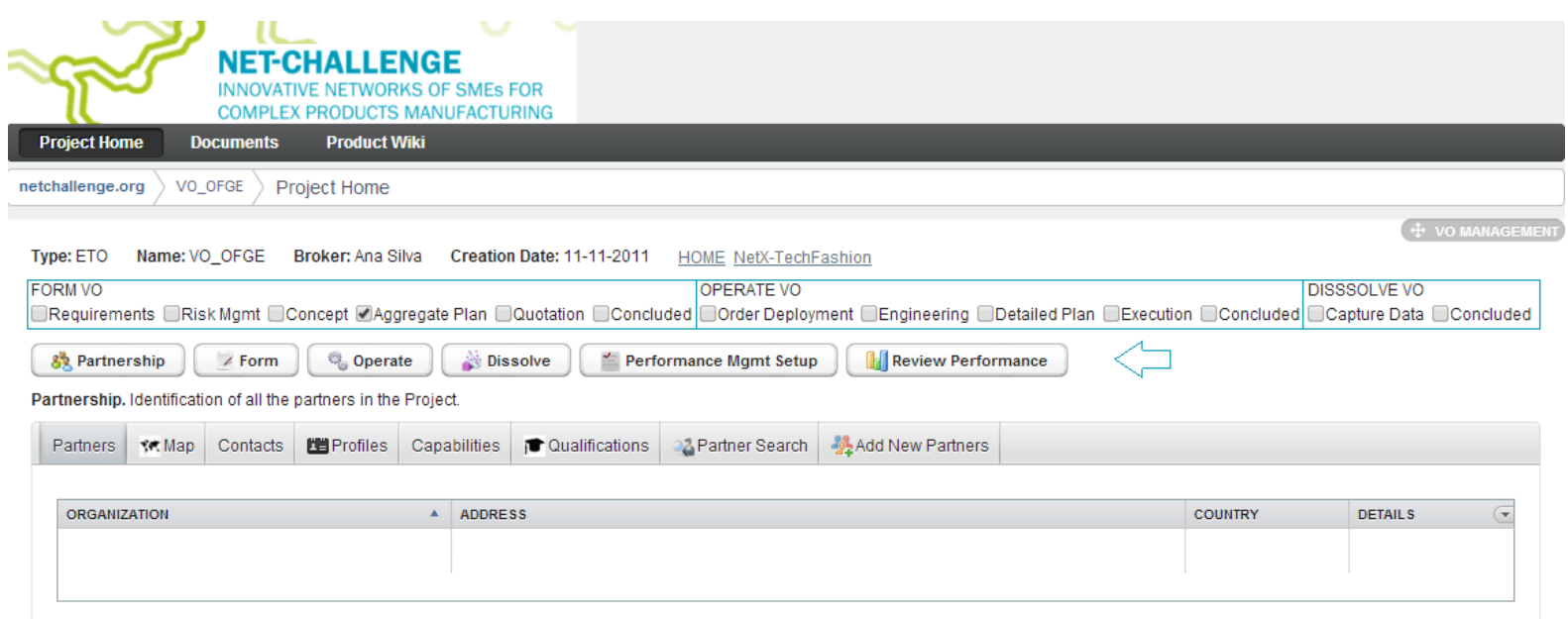

Figure 3: Workspace for forming and operating a Collaborative Project

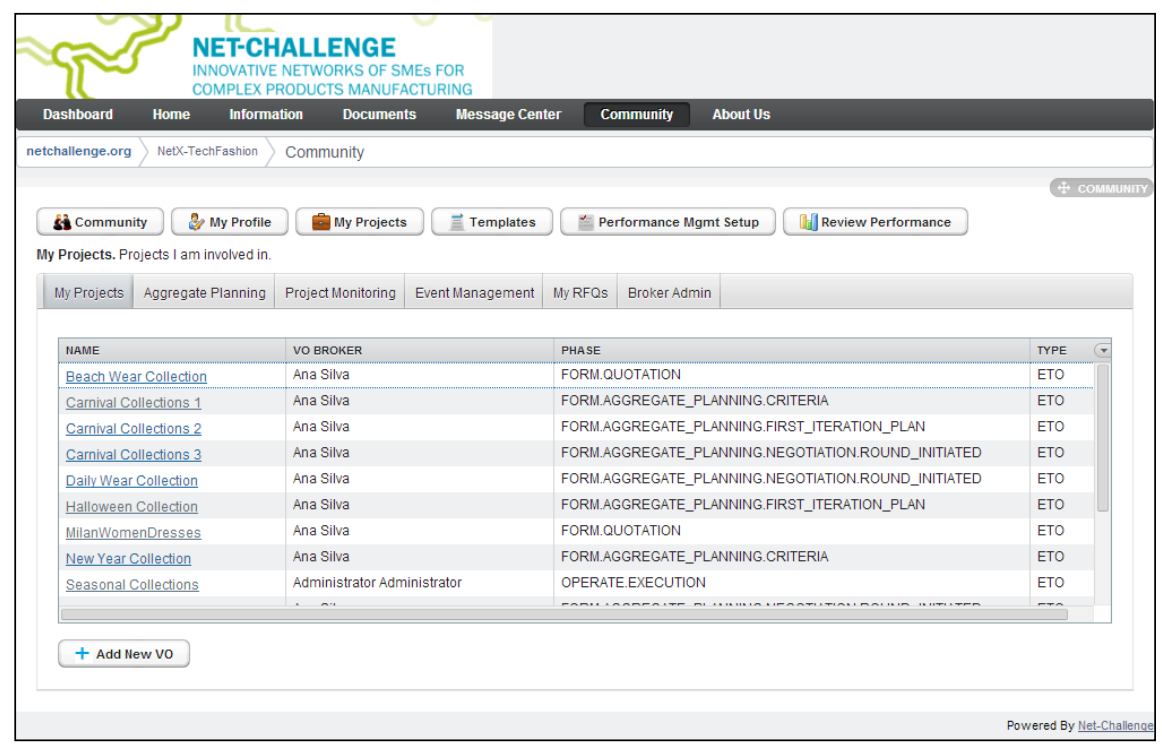

Figure 4: Workspace for forming and operating a Business Community

The collaboration infrastructure for business communities (Figure 4) provides the workspace for promoting information and knowledge sharing activities between members in a given community. The module provides two types of communities: open communities, open 
to any kind of organization, and restricted communities, where members must be invited by any member in the community and must fulfil the requirements defined by the community. The performance management module (Ferreira et al., 2012) is transversal to both communities and virtual organizations.

\subsection{Supporting Technology}

Given the key requirements identified in section 6.2 and the design described above, Liferay Portal (http://www.liferay.com/), an Open Source project implementing a content management system with portal and collaboration oriented functionality was selected to be the foundation of the Net-Challenge ICT Platform. This is shown in Figure 5. By itself, Liferay Portal provides a vast range of collaboration tools (document repository, Wiki, message boards, blogs) in an open and flexible way, allowing instances of these tools to be laid out on the screen in a very friendly way. Additionally, different layouts may be produced in the form of templates, enabling the dynamic creation of different workspaces. In the NetChallenge ICT Platform, this feature is used to enable the creation of different instances of Business Communities and different collaboration projects (e.g., ETO or CTO), starting from pre-established layouts.

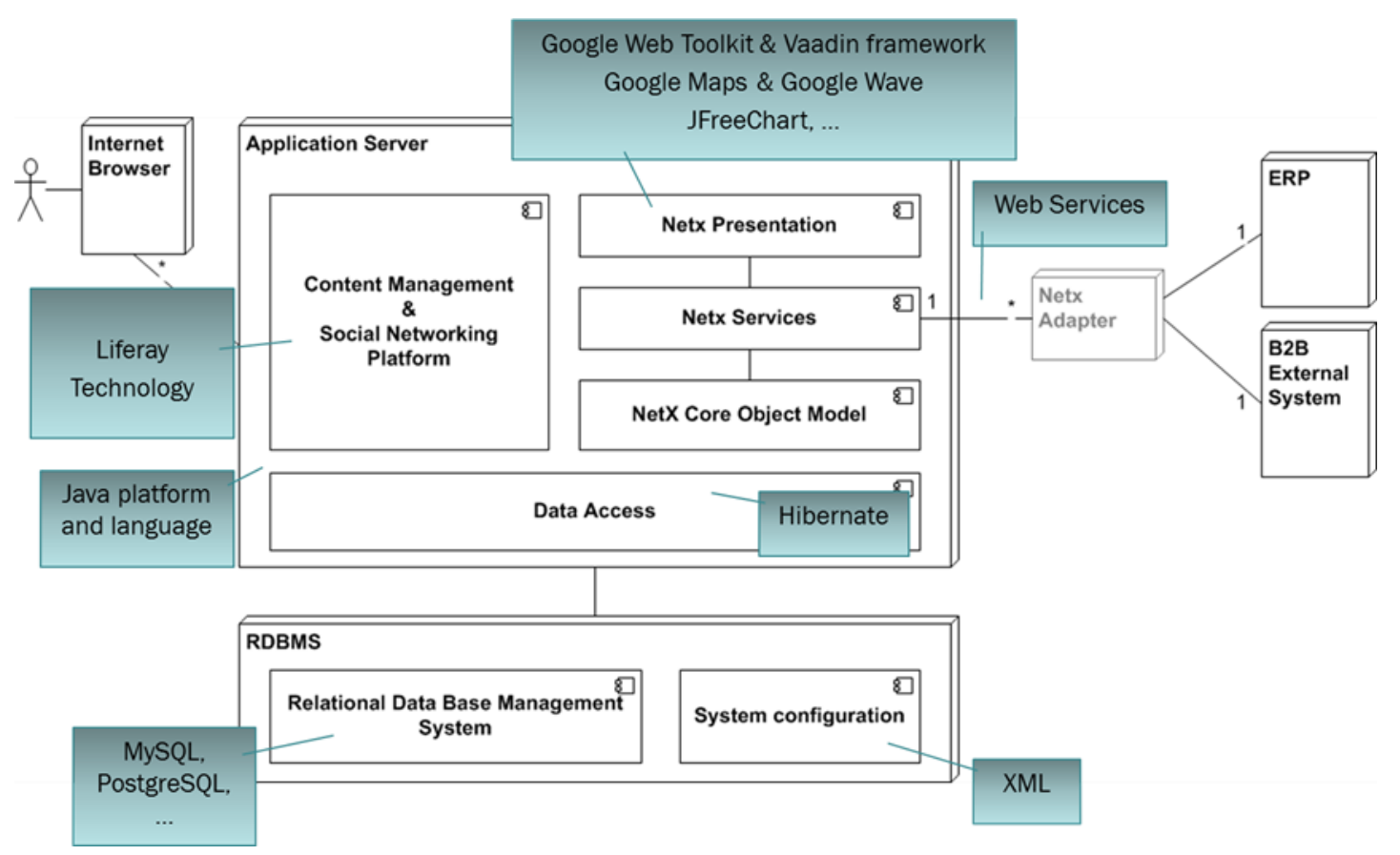

Figure 5: Supporting technology of the Net-Challenge Platform

On the other hand, Liferay Portal supports the incorporation of external software modules (provided they fulfil a given API), allowing the templates and the user interfaces they generate to contain not only Liferay existing modules but also the Net-Challenge specific decision support tools (partner search and product concept, product platform, collaborative planning and monitoring and event management). As depicted in Figure 5, these tools are supported by the Google Web Toolkit (http://www.gwtproject.org/), an open source set of tools that allows web developers to create and maintain complex JavaScript front-end applications in Java, and by the Vaadin Framework (https://vaadin.com/), which eases the development of java-based web applications on top of the Google Web Toolkit. 
The core information model of Liferay Portal was another strong argument for its selection. Users, organizations and groups of the previous entities are mapped and extended by the key Net-Challenge concepts of Business Community, Virtual Organization, VO Broker and BC Facilitator. This enabled Liferay's security and access control mechanisms to be extended to the Net-Challenge decision support tools.

Persistency of data is assured by a relational data base management system, while the mapping of the object oriented model to the relational model is taken care by Hibernate ORM (http://hibernate.org/orm/), one of the most popular open source frameworks in this domain.

As depicted in the diagram, all information supporting the decision support tools (partner search, product concept, planning, monitoring and event management, and performance management) are stored at this unique central data base. A distributed approach could have been taken, by developing autonomous applications with completely separate data base instances. However, the complexity of such a system would turn the software development into a very complex task, opening the door to interoperation issues that were out of scope. The design and software implementation of the aimed decision support tools in the framework of an open content management system (Liferay Portal) proved to be manageable, allowing future instantiations of the Net-Challenge Platform to be managed by an ICT company, providing their services to a community of SME. However, for supporting real time order monitoring (i.e., operations in a VO), a set of SOAP web services were designed in order to import order state from partners' ERP systems. This was restricted to the specific cases of textile, clothing and footwear sectors, through the help of the eBIZ-TCF reference architecture (http://www.ebiz-tcf.eu/), now a CEN Workshop Agreement (CWA 16667).

\subsection{Specify customer requirements}

In the very first step in the formation of a given Collaborative Project, the Broker must identify and analyse the customer requirements after rigorous market survey, which identifies the specific business opportunity. They are collected and screened out in order to prioritize the requirements based on different predefined criterions or factors. Most projects have general requirements such as delivery due date, total price and total quality, elements that will be used later on to assess the feasibility of the project, and specific requirements more related to the technical properties the product must comply with.

\subsection{Search for partners}

The next step is to search the community for partners that could participate in the fulfilment of the identified business opportunity and thus be part of the collaborative project. This search is based on information available at the related community. Each member in the community must have fulfilled a set of data (its profile) during its admission: identification of contact persons, name and location, identification of target markets, manufactured products, reference clients and projects, quality and production certifications, etc. Furthermore, organizations are demanded by the community Facilitator to identify its technical capabilities. Figure 6 illustrates the characterization made in a community operating in the textile/apparel industry: identification of process, processed product/component and applicable technical feature. For instance, second member in Figure 6 states that he is able to stamp fabric with length up to 10.000 meters on a week basis. Additionally, members' technical capabilities may be qualified by the remaining members in the community, so that information is more reliable. Within the context of a given collaborative project and given the specific customer requirements, information about members can be searched and used to create invitations that are sent to the respective organizations. According to the Net-Challenge Methodology, this 
should be realized in parallel with the product concept so that invitations are created in the context of a given activity (supply, manufacturing, distribution) in the delivery of the product.

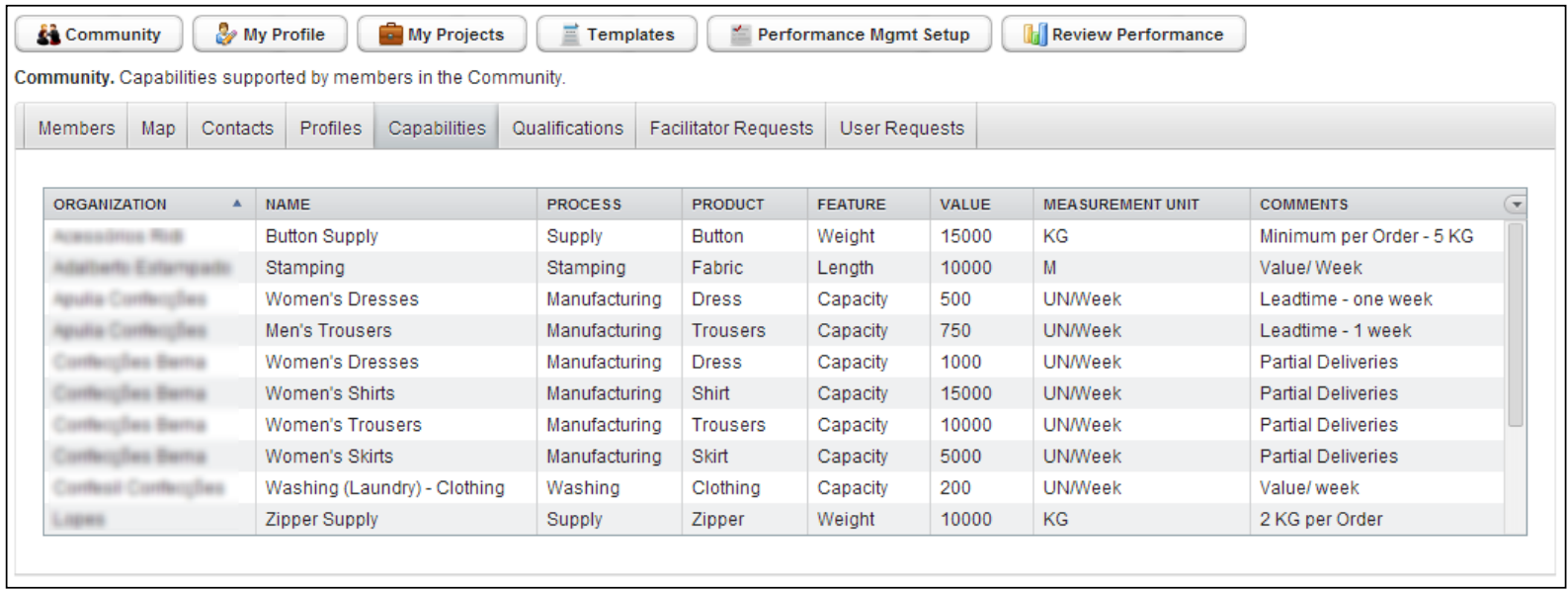

Figure 6: Technical capabilities of each member in the community

\subsection{Document the project}

In any business collaboration, a document library is necessary for keeping and sharing among the partners essential documents for smoothly forming and operating the project. This library often contains different folders within which various documents can be added or stored for future use. These folders might contain the important information related with customer requirements, customer quotation, partner contracts, product concept, project contract, etc. These folders can be opened, edited and deleted following required access code or permission. All the partners in the collaborative project have the permission to open and access the information repository from this document library. Figure 7 presents a sample document library as developed within the ICT Platform.

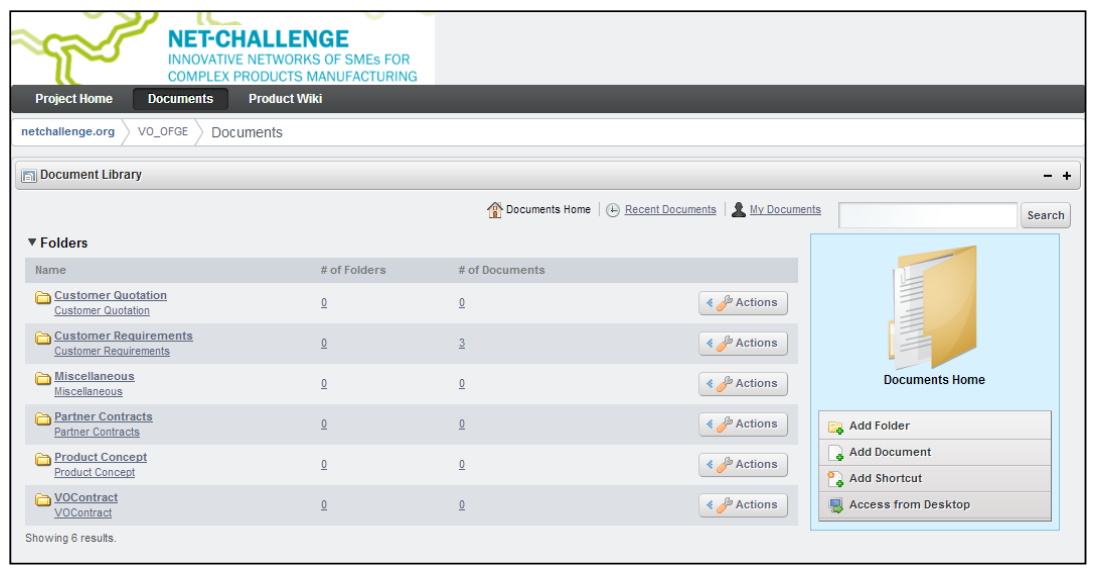

Figure 7: Document library

Contracts, non-disclosure agreements, business models and any documents intended to regulate the formation and operation of the project should be defined and stored in the document library. In this context, the best practices possibly defined in the related business community in the form of documents may be imported and adapted. This activity may be 
realized by the Broker alone or in collaboration with the core partners already invited throughout the Platforms' collaboration tools (wiki, message boards and blogs). No innovation activities were foreseen by the Net-Challenge Framework.

\subsection{Create the product concept}

The development of the product concept is an essential step in the formation of a collaborative project. This aims at defining the needed bill-of-materials (BOM), including parts list, parts interfacing with each other and required components/materials, and corresponding bill of operations (BOO) and their allocation to the partners in the project. Partners also need to identify the corresponding suppliers responsible to supply the individual materials as needed to manufacture the required parts.

Figure 8 displays the sample product concept (for a footwear product), where different information related to the parts such as name of the parts, their descriptions (product code, quantity, cost, material, etc.), suppliers' details (name, URL address, etc.) are collected and stored within the ICT Platform. Search and selection of partners is imbricated in the product concept activity. In most cases, the Broker is the leading actor in the product concept activity, but any partner that accepts to participate in the project (after having agreed on the nondisclosure documents and contractual documents initially set by the Broker) is demanded to actively participate in the process.

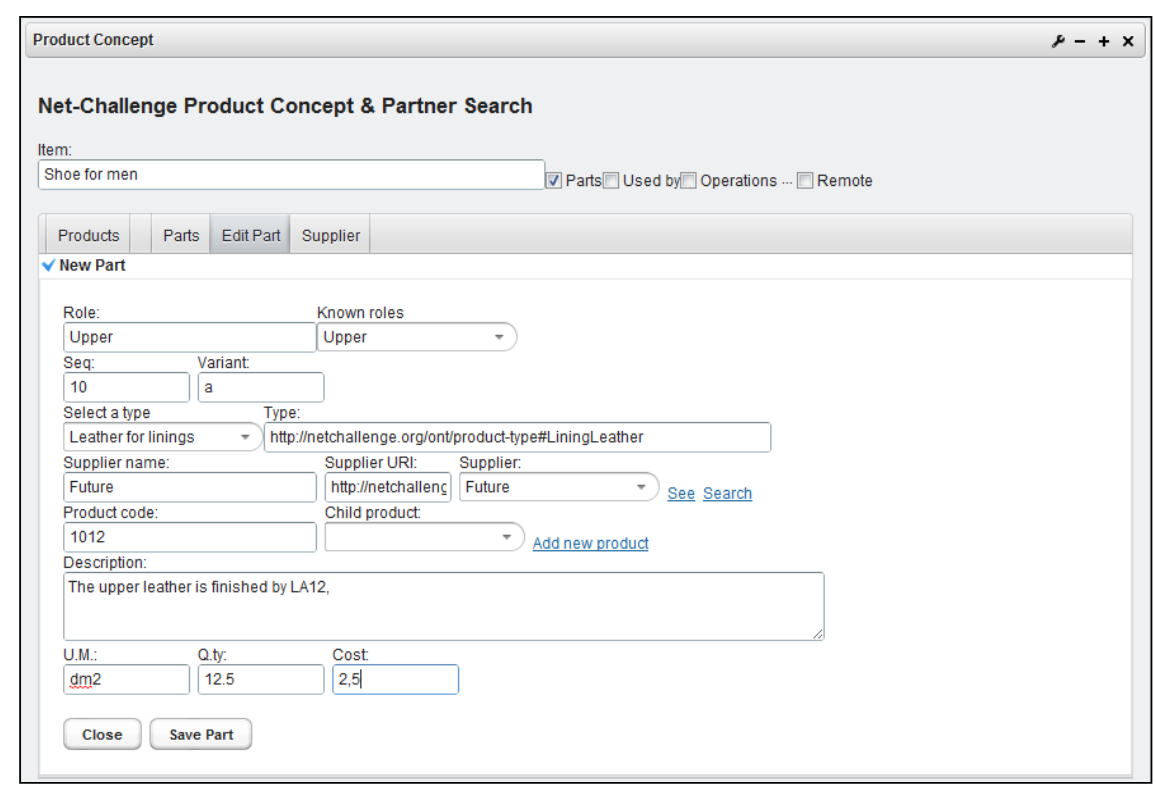

Figure 8: Product concept and bill-of-materials

Figure 9 shows the support of the Platform to the specification of the BOM. Partners within the project need to define the major operations required to manufacture/assemble/distribute the product that is being conceived, so as to identify the operation name, type of operation, partner/supplier responsible for specific operation, operational sequence, etc. 


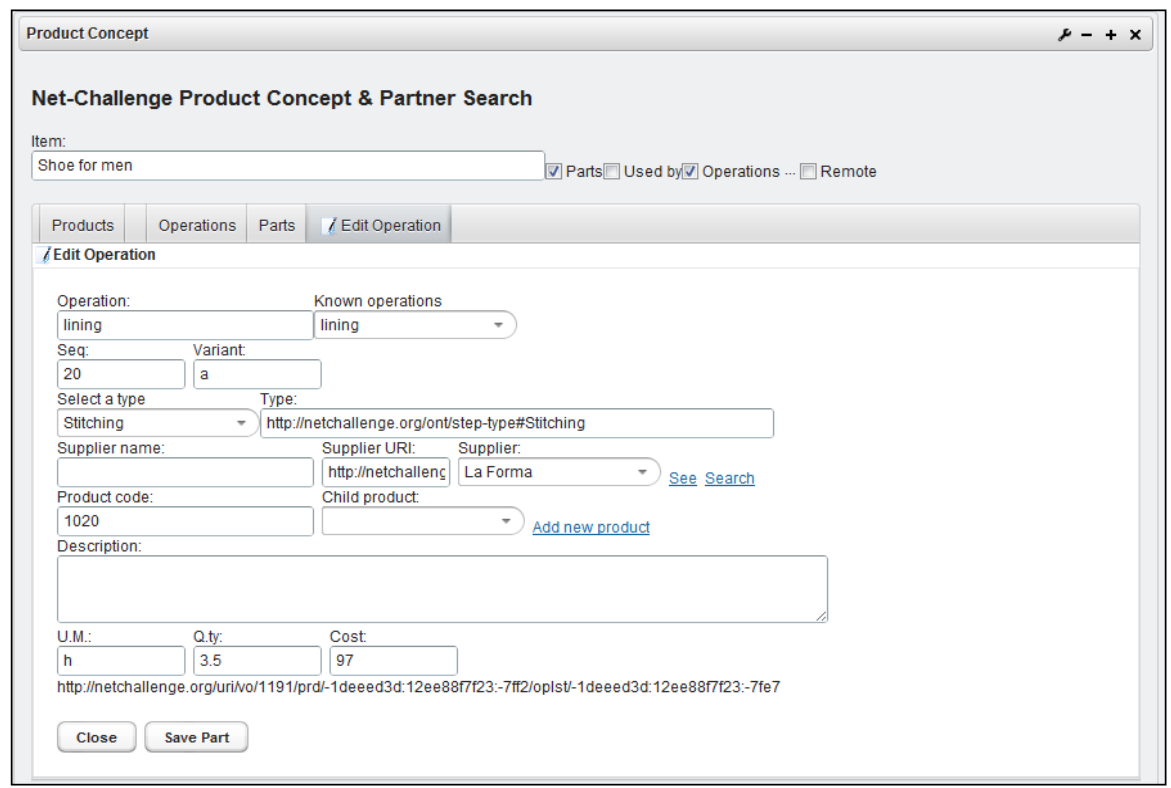

Figure 9: Product concept and bill-of-operations

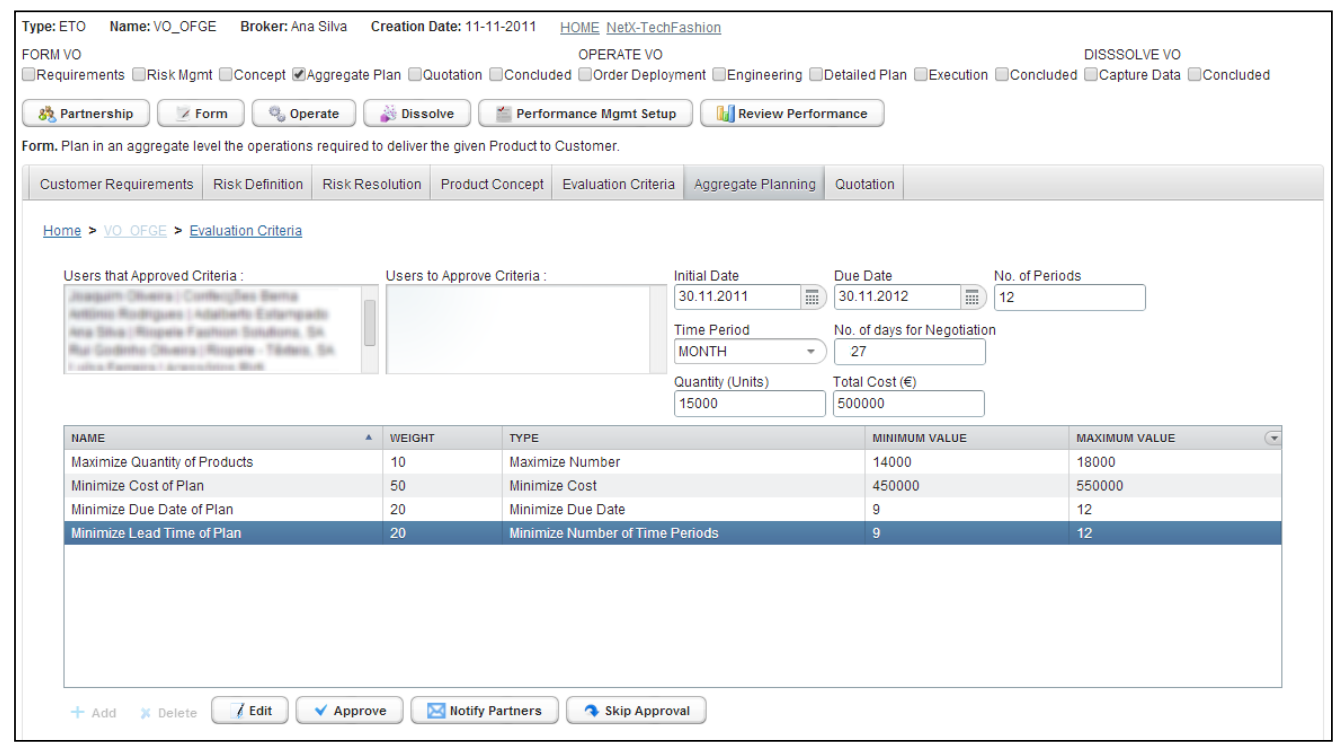

Figure 10: Specification of planning criteria in the aggregate planning

\subsection{Collaborative planning among the partners}

In designing and developing the product, partners need to plan their allocated individual activities. This planning stage is done in two steps known as aggregate planning and detailed planning (Almeida et al, 2013). The aggregate planning is done just after the product concept and gives an overall idea of how operations may be sequenced, how much time each one requires, total cost of each operation, and finishing due date. A negotiation-based conversation is carried between the partners so that each one states their cost for realizing a given operation in a certain due date, within a given lead-time, for producing a given quantity of parts for the product in response to requests generated by any other partner. Each partner is thus allowed to create requests for quotations to any other partner in the project and is expected to provide quotation (specifying lead times, due dates and costs) to any request. First 
plan is created by the VO Broker, functioning as a starting point in the approach. The goal is to collaboratively achieve several aggregate plans, with different characteristics in terms of costs, due dates, lead times and product quantities. In order to quantify and serialize the plans produced so far, specific criteria (see Figure 10) must be initially defined and agreed by all the partners. Additionally, a maximum timeout is initially defined for each iteration and for the whole process. When these conditions are met, the best plan (according to the defined criteria) is chosen.

In the detailed planning step, a list of the tasks and activities of individual partners are scheduled, monitored and updated from time to time based on the actual progress. In this context, a Gantt chart is provided in the ICT Platform to visually identify the operations' progress. On this Gantt chart (Figure 11), each of the partners' progress is made available to the other partners and displayed in a real-time environment. From this chart, the VO partners could estimate their progress and adjust their schedule based on the up-to-date information.

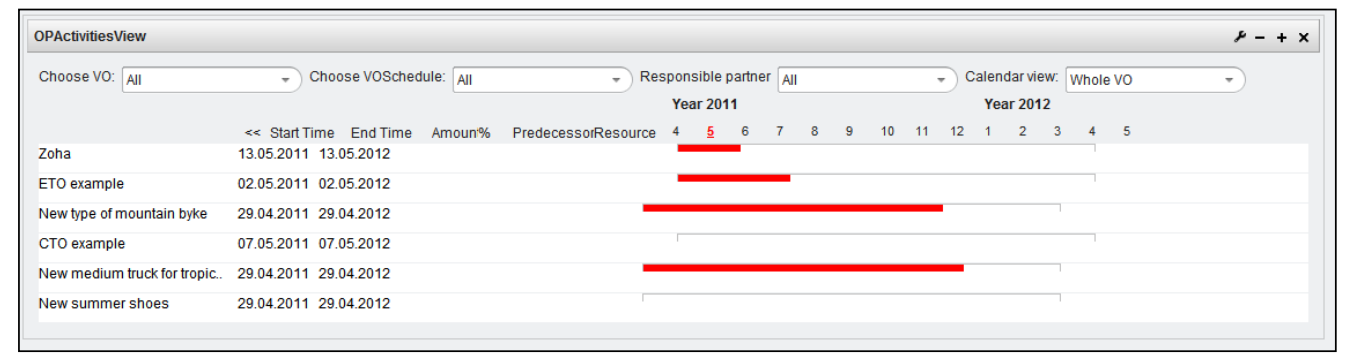

Figure 11: Display of detailed operational planning within a collaborative project

\subsection{Monitoring and managing abnormalities in process execution}

In order to keep the aggregate and detailed planning according to schedule, partners need to continuously monitor and manage the uneven situations, known as 'events' in operational processes. Monitoring the operational process in a collaborative project is organized by investigating the individual partners' tasks, as displayed in Figure 12. Individual partners have their own task schedule based on their committed due dates and lead times. Its progress is reported as a percentage. If there are any deviations within the tasks schedule, necessary steps need to be taken to adjust it. All the partners in the collaborative project (virtual organization) visualize and monitor on each other's progress in a real-time environment and adjust their scheduled tasks accordingly if necessary.

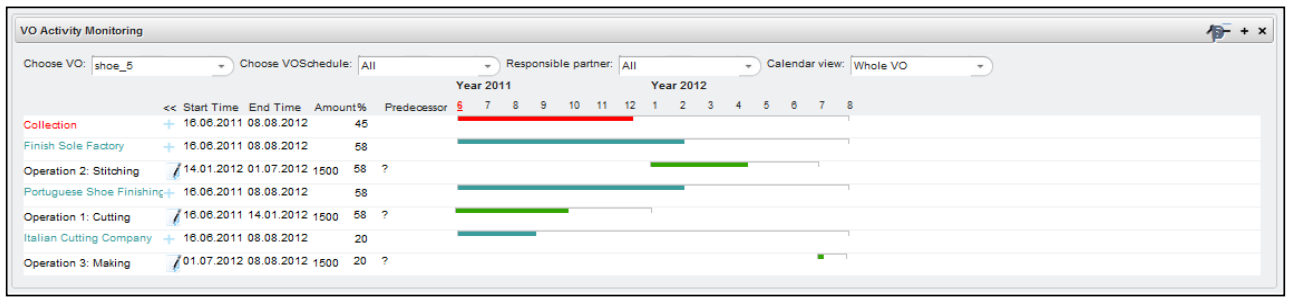

Figure 12: Tasks monitoring within a collaborative project

Abnormal situations may arise during the execution of an operational process within a collaborative project. These may be related with machine breakdowns, shortage of materials, labour unrest/strike, etc. These abnormal conditions need to be detected and managed in order 
to avoid delivery delays in the process. In the Net-Challenge Platform, events which hamper the production processes are firstly characterized, and then monitored, detected, prioritized and controlled as soon as they occur. Otherwise, they may create complete schedule chaos within the collaborative network. Figure 13 outlines the data elements of an event and the various management actions. This event window is used to identify basic information about specific conditions in the process, associated risks and possible deviations from the normal expected condition, including the identification of what resolutions and notification actions should be undertaken by which partner in the virtual organization.

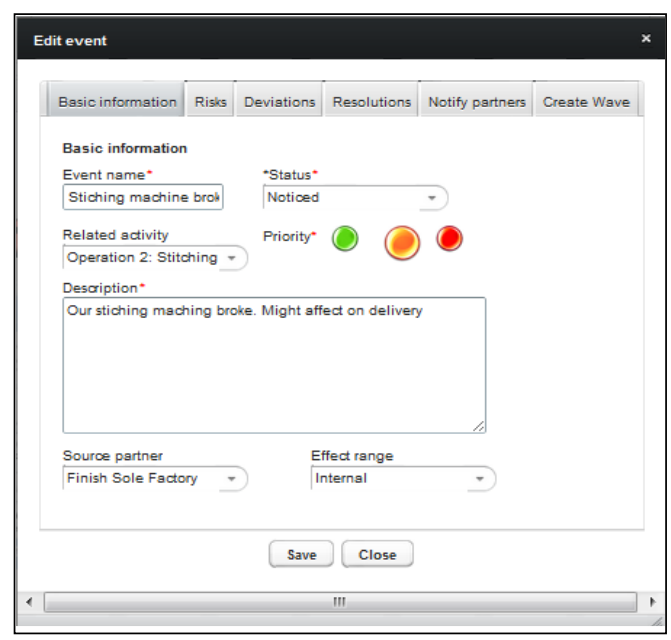

Figure 13 Characterization of an event (abnormal situation) in a collaborative project

\subsection{Monitoring operations with IoT technologies}

Monitoring of operations, the identification of deviations to a predefined plan, the identification of other events and the reaction to its occurrence are important issues in a virtual organization operation. Events are usually categorized in terms of their detrimental effect on the production process and often displayed with various colour codes such as red, yellow and green. Events with a red colour signify highest priority to manage while yellow and green colours identify medium and low priority respectively. Figure 14 displays a sample event management window as developed by using the ICT-based tool. This window shows the location of the partner organization and where the event occurred in the map. It also displays its status, priority and occurrence time.

The monitoring of certain events like the start or finishing of an operation may be automatically captured with RFID technology or other IoT technologies. In this specific application of smart objects, an RFID-based event is a description of a certain class of tags that are expected to be read in certain locations of the business process. The start and finish time of process steps are mapped to RFID-based readings and these sensor data is expected to arise in certain time windows in the execution of the process. In case they are not generated inside the defined time window, an event is raised and a resolution procedure is followed. In the case example presented in this section, it was also implemented the possibility for workers to inform the system through manual SMS messages, which can be an interesting possibility when the operation is executed in a small and remote site without connectivity or RFID readers. 


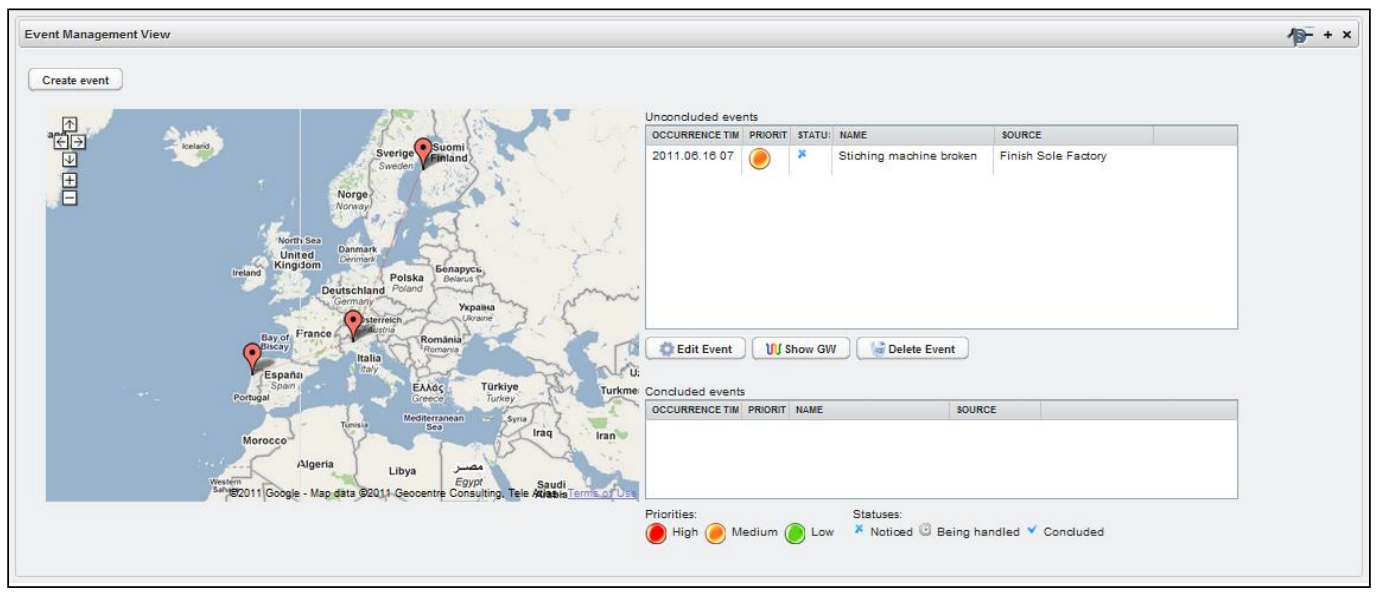

Figure 14: Display of an event management window within a VO

\section{$7 \quad$ Managerial implications}

\section{(a) Collaborative business point of view}

In order to survive in current business world, manufacturing firms need to be innovative in terms of product design and manufacturing capabilities. The issue of product design is usually so complex and often needs lots of information exchange associated with constant design improvements. It also inherits substantial amount of resource consumptions and requires interpretation of knowledge and expertise. The goal of manufacturing firms is to develop more products in a shorter period of time. Collaborative product development, combining product design and engineering, can be the beginning of the time saving revolution by working cross-functionality. Today's competitive business, manufacturing firms are seeking the ability to leverage the expertise of qualified partners to gain new proficiency beyond their own core competencies. The basic theme of this initiative is to divide product development project work among potential partners to develop product parts/components in parallel, shortening lead time.

In such collaborative environment, firms' managers need to accumulate the combined resources and to distribute the developmental tasks among the partner organizations. This can ensure to reduce the time to market acceptance as partners work together with the objective to achieve new market segments for total customer solutions. The collaborative product development supports firms' managers to be able to generate, transform, and distribute knowledge that consequently offered customers value in the market place and gaining competitive edge. In collaboration, managers need to maintain both layers namely collaboration layer, where the information related with project management, structured design, real-time design information and social interactions among partners are maintained, and control layer, where intellectual property rights, database, product data registry and product data management are maintained for quality product development (Lasser, 2003).

Before promoting any form of collaboration among firms, especially SMEs, managers of individual firms are required to establish an effective and efficient communication infrastructure. This infrastructure supports the real time information update among the partners, corresponding to individual operational status including bottlenecks and/or abnormalities. The exploitation of ICT/Web-based technology or tool in the Internet and World Wide Web provide such communication infrastructure that impacts the coordination of partners' business activities. These tools provide round the clock (24/7) product development information via synchronous and asynchronous technology such as email and instant 
messages (SMS). This information flow among partner organizations within a VO ensures on time product development process in a collaborative manner and creates the costly trust and motivation to the business organizations.

\section{(b) Validation point of view}

The Net-Challenge ICT Platform presented in the above section was assessed in three different industry domains, namely the textile and apparel, the footwear and the machine tools, in Portugal, Italy and Spain, respectively. Two SMEs leaded the assessment within each use case, creating a closed $\mathrm{BC}$ and inviting six to ten firms to participate to participate in the $\mathrm{BC}$ according to their elective interests. In total six firms, two from each three different industry domains were participated in the online questionnaires process to validate the proposed ICT platform. In all the three different industry domains, the tools available at the $\mathrm{BC}$ level were evaluated as adding value to their pre-order activities as the tools allowed each firm to know the technical capabilities (products, processes and technical features) of the remaining members in the $\mathrm{BC}$ and as this information was initially stated by each firm but later on qualified by other members in the $\mathrm{BC}$, information was considered to be more reliable and accurate. In all the cases, this contributed to an easier and faster selection of members while creating a VO in the BC. Also, firms valued the advertisement of their qualified capabilities outside the BC, i.e. at the Internet.

Additionally, in the footwear use case, the platform allowed the members to have a common background of knowledge and language as the $\mathrm{BC}$ facilitator had a proactive role and shared information about the conception, design and production of footwear with healthy characteristics, characterizing the target market segment related to the demand for fashion and the need for specific functional and healthy characteristics. Sustainability of the product, including the aspects of ecology values, care during product dismissal, and measurement of the environmental impact of production processes, was the main theme treated by the $\mathrm{BC}$ Facilitator.

At the formation and operation of a VO, the degree of usage of the decision support tools was different in the three use cases. In the footwear use case, the focus was to design a collection of shoes with specific healthy features, considering the requests of a stylist (acting as VO customer), and to produce a set of prototypes. In this context, the design of the collection was the most complex activity and the product concept decision support tool was the most appreciated tool. The tool allowed the selected firms to collaborate with the VO Broker in specifying all the components and accessories needed for each shoe model in the collection and to manage all such information in a common environment.

On the other hand, the VO created in the textile and apparel use case, focused on the design and production of thousands of military uniforms, comprised by three pieces of clothing: shirts, dolmans and trousers. In this context, the collaborative planning decision support tool proved to be the most appreciated tool as the key challenge was to achieve the best partial delivery dates at the smallest price. Real-time negotiation between the selected partners about their costs, their production capacities and partial delivery dates allowed the partners to generate and evaluate a set of production and distribution plans and to select the one maximizing the initially defined criteria.

In the machine tool use case, the design and manufacture of an automated EDM cell for producing tools, injection molding and die casting molds was the target of the formed VO. In this scenario, the involved firms elected the risk and event management the most valuable decision support tool in the Net-Challenge ICT Platform. The former experience of the two leading members in the $\mathrm{BC}$, allowed them to build a knowledge data for solving problems that have happened in the past, in the form of identification of risks and of possible resolutions. 
This was defined at the $\mathrm{BC}$ level and imported to the $\mathrm{VO}$ at hand. The approach allowed the identification of questions and proposed solutions that traditionally are not covered.

\section{Discussion and conclusions}

The increasing trends of shorter product life cycle push manufacturing firms globally to be innovative in order to reduce the product development lead time. This objective puts enormous pressure on product engineering activities including design, production, logistics, etc., to be performed with higher quality in shorter time frame. In this research, a collaborative product design, development and manufacturing approach is presented with the view to be competitive and gain success in the market place. The basic needs for collaborative work are corresponding to product globalization that affects customers and push towards rapid product replacement. Manufacturing firms, especially the SMEs, are struggling to compete to get their products on the market first (time-to-market). To tackle such calamities, geographically spread SMEs need to cooperate and exploit their resources through the formation and operation of virtual organization.

During formation and operationalization of the VO, the collaborative firms (SMEs) require a secure environment for sharing valuable information among their networked partners. A mutual identity and real time information sharing bridge the gaps that might exist among the partners. The most successful collaborative environment demonstrates the ability to share and synchronize the information and to utilize it to increase the trust among the partners. Therefore, the need to develop ICT-based communication infrastructure is crucial for running an effective and efficient collaborative network like VO or virtual enterprise (VE). This ICT/Web-based tool or internet based communication infrastructure ensures partners to be able to perform activities electronically related with product development and production to cooperate with other participating partners in the network.

Typically, collaborative product design and development is highly iterative and interactive activity involves among geographically dispersed designers. In such environment, ICT-based tool supports to required information exchange among partners corresponding to product design, engineering and manufacturing processes. This platform accumulated key operations among the manufacturing firms which are globally distributed. In this research, a supportive collaborative environment is presented with the view to develop collaborative product design and manufacturing with production scheduling and operational monitoring. It is hoped that this operational guideline will enhanced the globalized product development process among manufacturing firms, especially SMEs. Every aspect of developing the collaborative product such as partners selection process, formation of VO, product concept, production scheduling, essential planning (aggregate and detailed), production monitoring (event monitoring and control), etc., are illustrated in this paper.

This research was focused to the implementation perspective of ICT solutions in the collaborative business environment. These solutions are mainly focused in the forms of establishing communication infrastructure and smart process monitoring between business partners within the VO network. The communication infrastructure as established within this research study is supported by the ICT platform contributes to form and document a collaborative VO, store partners' information, initiate collaborative planning, deploy and fulfil an order within VO. On the other hand, the implementation of IoT-based technology and tool in this research provided necessary support to smart process monitoring that enables to avoid or minimize both known and unknown events and risks within the VO.

In the future research, this study will be extended towards the implementation of cloudbased data repository system that supports the data/information storage and retrieval facility within the VO. This cloud repository system works as an extension of VO process monitoring 
system, where various processes related data/information be stored and retrieved according to the specific requirements.

\section{References}

Aarikka-Stenroos, L. and Jaakkola, E. (2012) 'Value co-creation in knowledge intensive business services: a dyadic perspective on the joint problem solving process', Industrial Marketing Management, Vol. 41, No. 1, pp. 15-26.

Afsarmanesh, H. and Thamburaj, V. (2012) 'ICT requirements analysis for enterprise networks supporting solar power plants', Camarinha-Matos, L.M., Xu, L. and Afsarmanesh. H. (Eds.): PRO-VE 2012, IFIP AICT 380, pp. 149-157.

Alarcon, F., Alemany, M.M.E. and Ortiz, A. (2009) 'Conceptual framework for the characterization of the order promising process in a collaborative selling network context', International Journal of Production Economics, Vol. 120 No. 1, pp. 100-114.

Almeida, R. and Azevedo, A. (2011) 'Collaborative business networks: evaluation of technological tools for decision support making', E-LP Engineering and Technology Journal, Vol. 2, pp. 97-118.

Almeida, Ricardo; Toscano, César; Azevedo, Américo; Carneiro, Luis. (2013) 'A Collaborative Planning Approach for Non-hierarchical Production Networks', In "Intelligent Non-hierarchical Manufacturing Networks", ed. Raúl Poler et all, Willey, 2013, p. 185-203, ISBN: 9781848214811.

Atzori, L., Iera, A. and Morabito, G. (2010), 'The Internet of Things: a survey', Computer Networks, Vol. 54 No. 10, pp. 2787-2805.

Barczak, G., Sultan, F. and Hultink, E.J. (2007) 'Determinants of IT usage and new product performance', Journal of Product Innovation Management, Vol. 24, pp. 600-613.

Benbya, H., Passiante, G. and Belbaly, N. A. (2004) 'Corporate portal: a tool for knowledge management synchronization', International Journal of Information Management, Vol. 24, pp. 201-220.

Bi, Z., Xu, L.D. and Wang, C. (2014) 'Internet of things for enterprise systems of modern manufacturing', IEEE Transactions on Industrial Informatics, Vol. 10, No. 2, pp. 15371546.

Buttol, P., Buonamici, R., Naldesi, L., Rinaldi, C., Zamagni, A. and Masoni, P. (2012) 'Integrating services and tools in an ICT platform to support eco-innovation in SMEs', Clean Technologies and Environment Policy, Vol. 14, pp. 211-221.

Büyüközkan, G. and Arsenyan, J. (2012) 'Collaborative product development: a literature overview', Production Planning \& Control, Vol. 23 No. 1, pp. 47-66.

Camarinha-Matos, L.M. (2009) 'Collaborative networked organizations: Status and trends in manufacturing', Annual Reviews in Control, pp. 199-208.

Camarinha-Matos, L.M. and Abreu, A. (2005) 'A contribution to understand collaboration benefits', Emerging solutions for future manufacturing systems - IFIP International Federation for Information Processing, Vol. 159, pp. 281-298.

Camarinha-Matos, L.M. (2005) 'ICT infrastructures for VO', Virtual Organizations, pp. 83104. 
Camarinha-Matos, L.M., Afsarmanesh, H., Galeano, N. and Molina, A. (2009) 'Collaborative networked organizations - concepts and practice in manufacturing enterprise', Computers and Industrial Engineering, Vol. 57 No. 1, pp. 46-60.

Camarinha-Matos, L.M. and Afsarmanesh, H. (2008) Collaborative Networks: Reference Modeling', United Kingdom, Edition: Springer Science+Business Media, LLC. ISBN13:978-0-387-79426-6

Campos, J. (2009) 'Development in the application of ICT in condition monitoring and maintenance', Computers in Industry, Vol. 60, No. 1, pp. 1-20.

Carneiro, L., Shamsuzoha, A., Almeida, R., Azevedo, A., Fornasiero, R. and Ferreira, P.S. (2014) 'Reference model for collaborative manufacturing of customized products: applications in the fashion industry', Production Planning and Control, Vol. 25, No. 13-14, pp. 1135-1155.

Carneiro, L.M., Soares, A.L., Patricio, R., Azevedo, A.L. and Pinho de Sousa, J. (2013) 'Case studies on collaboration, technology and performance factors in business networks', International Journal of Computer Integrated Manufacturing, Vol. 26, No. 1-2, pp. 125-139.

Carneiro, L., Almeida, R., Azevedo, A.L., Kankaanpää, T. and Shamsuzzoha, A. (2010) 'An innovative framework supporting SME networks for complex product manufacturing', in Collaborative Networks for a Sustainable World (11 ${ }^{\text {th }}$ IFIP WG 5.5 Working Conference on Virtual Enterprises, PRO-VE 2010, Saint-Etienne, France, October 2010 Proceedings), Camarinha-Matos, L.M., Boucher, X. and Afsarmanesh, H. Edition, Springer.

Cavalieri, S. and Pezzotta, G. (2012) 'Product-service systems engineering: state of the art and research challenges', Computers in Industry, Vol. 63, No. 4, pp. 278-288.

Cecily, M., Castleman, T. and Parker, C. (2011) 'Communities of enterprise: SMEs, Webbased and regional development', http://csrc.lse.ac.uk/asp/aspecis/20060087.pdf, Retrieved on $17^{\text {th }}$ October 2011.

Chan, F.T.S., Chong, A.Y-L. and Zhou, L. (2012) 'An empirical investigation of factors affecting e-collaboration diffusion in SMEs', International Journal of Production Economics, Vol. 138 No. 2, pp. 562-573.

Cheikhrouhou, N., Pouly, M., Huber, C. Choudhary, A. (2011) 'An empirical study on human and information technology aspects in collaborative enterprise networks', Journal of Universal Computer Science, Vol. 17, No. 2, pp. 203-223.

Chituc, C.-M., Azevedo, A. and Toscano, C. (2009) 'A framework proposal for seamless interoperability in a collaborative networked environment', Computers in Industry, Vol. 60, No. 5, pp. 317-338.

Choudhary, A.K., Harding, J., Camarinha-Matos, L.M., Koh, S.C.L. and Tiwari, M.K. (2013) 'Knowledge management and supporting tools for collaborative networks', International Journal of Production Research, Vol. 51 No. 7, pp. 1953-1957.

Crispim, J.A. and Pinho de Sousa, J. (2010) 'Partner selection in virtual enterprises', International Journal of Production Research, Vol. 48, No. 3, pp. 683-707.

Chryssolouris G., Pappas M., Karabatsou V., Mavrikios D. and Alexopoulos K. (2007) 'A shared VE for collaborative product development in manufacturing enterprises', Collaborative Product Design and Manufacturing Methodologies and Applications (ISBN: 978-1-84628-801-2), Li W.D., Ong S.K., Nee A.Y.C. and McMahon C. (Eds.), Springer Series in Advanced Manufacturing, Springer-Verlag, London.

Chryssolouris, G., Mavrikios, D., Peppas, M., Xanthakis, E. and Smparounis, K. (2009) 'A web and virtual reality-based platform for collaborative product review and 
customisation' in: Wang, L. and Nee, A.Y.C (Eds.), Collaborative Design and Planning for Digital Manufacturing, Springer-Verlag London Limited.

Chu, C-H., Cheng, C-Y. and Wu, C-W. (2006) 'Applications of the Web-based collaborative visualization in distributed product development', Computers in Industry, Vol. 57, No. 3, pp. 272-282.

de Berranger, P., Tucker, D. and Jones, L. (2004) 'Internet diffusion in creative microbusinesses: identifying change agent characteristics as critical success factors', Journal of Organisational Computing and Electronic Commerce, Vol. 11, pp. 197-214.

de Campos, P.J.R.M (2007) Organizational Survival and the Emergence of Collaboration Networks: a Multi-Agent Approach, Tese de Doutoramento em Ciências Empresariais (Faculdade de Economia - Universidade do Porto, 2007), http://www.box.net/shared/mk82q2fuv1.

Doloreux, D. and Shearmur, R. (2012) 'Collaboration, information and the geography of innovation in knowledge intensive business service', Journal of Economic Geography, Vol. 12, No. 1, pp. 79-105.

Durugbo, C. and Riedel, J.C.K.H. (2013) 'Readiness assessment of collaborative networked organizations for integrated product and service delivery', International Journal of Production Research, Vol. 51 No. 2, pp. 598-613.

Dutton, W.H. (2008) 'The wisdom of collaborative network organizations: capturing the value of networked individuals', Prometheus: Critical Studies in Innovation, Vol. 26, No. 3, pp. 211-230.

Ebrahim, N.A., Ahmed, S. and Taha, Z. (2010) 'SMEs; virtual research and development (R\&D) teams and new product development: a literature review', International Journal of the Physical Sciences, Vol. 5, No. 7, pp. 916-930.

Evanschitzky, H., Eisend, M., Calantone, R.J. and Jiang, Y. (2012) 'Success factors of product innovation: an updated meta-analysis', Journal of Product Innovation Management, Vol. 29, No. 1, pp. 21-37.

Fan, Y., Wei, Y. and Xu, W. (2002) 'Virtual enterprise and its intelligence management', Computers \& Industrial Engineering, Vol. 42 No. 2-4, pp. 199-205.

Ferreira, P., Shamsuzzoha, A., Toscano, C. and Cunha, P. (2012) 'Framework for performance measurement and management in a collaborative business environment', International Journal of Productivity and Performance Management, Vol. 61, No. 6 pp. $672-690$.

Ferreira, F., Shamsuzzoha, A., Azevedo, A. and Helo, P. (2015) 'Virtual enterprise process monitoring: an approach towards predictive industrial maintenance', In: Selvaraj, H., Zydek, D. and Chmaj, G. (Eds.), Progress in Systems Engineering: Advances in Intelligent Systems and Computing, Springer International Publishing, Switzerland, Vol. 330, pp. 285-291.

Feser, E.J. and Bergman, E.M. (2000) 'National industry cluster templates: a framework for applied regional cluster analysis', Regional Studies, Vol. 34, No. 1, pp. 1-19.

Fielding, E.A.S., McCardle, J.R., Eynard, B., Hartman, N. and Fraser, A. (2014) 'Product lifecycle management in design and engineering education: international perspectives', Concurrent Engineering Research, Vol. 22, No. 2, pp. 123-134.

Forsgren, M. and Johanson, J. (2014) Managing Networks in International Business, Routledge Publisher, New York, USA.

Gebauer, H., Edvardsson, B., Gustafsson, A. and Witell, L. (2010) 'Match or mismatch: strategy-structure configurations in the service business of manufacturing companies', Journal of Service Research, Vol. 13, No. 2, pp. 198-215. 
Gunasekaran, A. and Ngai, W.W.T. (2009) 'Information systems in supply chain integration and management', European Journal of Operational Research, Vol. 159, pp. 269-295.

Hakansson, H. (2014) Corporate Technological Behaviour: Co-operation and Networks, Routledge Publisher, New York.

Haller, S., Karnouskos, S. and Schroth, C. (2009) 'The internet of things in an enterprise context', In: Domingue, J., Fensel, D. and Traverso, P. (Eds.), Future Internet-FIS 2008: First Future Internet Symposium, FIS 2008, Vienna, Austria, September 29-30, Vol. 5468, pp. 14-28.

Hao, Q., Shen, W., Zhang, Z., Park, S-W. and Lee, J-K. (2006) 'Agent-based collaborative product design engineering: an industrial case study', Computers in Industry, Vol. 57, No. 1, pp. 26-38.

Harmon, P. (2015) 'The scope and evolution of business process management', In: Brocke, J.v. and Rosemann, M. (Eds.), Handbook on Business Process Management: Introduction, Methods, and Information Systems, Part I, Springer Berlin Heidelberg, pp. 37-80.

He, Y. and Lai, K.K. (2012) 'Supply chain integration and service oriented transformation: evidence from Chinese equipment manufacturers', International Journal of Production Economics, Vol. 135, No. 2, pp. 791-799.

Hossain, L. and Wigand, R.T. (2004) 'ICT enabled virtual collaboration through trust', Journal of Computer-Mediated Communication, Vol. 10, No. 1.

Huang, G.Q. and Mak, K.L. (1999) 'Web-based collaborative conceptual design', Journal of Engineering Design, Vol. 10, No. 2, pp. 183-194.

Isenberg, M-A., Werthmann, D., Morales-Kluge, E. and Scholz-Reiter, B. (2011) 'The role of the Internet things for increased autonomy and agility in collaborative production environments', in D. Uckelmann et al. (eds), Architecturing the Internet of Things, Springer-Verlag Berlin, Heidelberg.

Isaksson , O., Larsson, T.C. and Rönnbäck, A.O. (2009) 'Development of product-service systems: challenges and opportunities for the manufacturing firm', Journal of Engineering Design, Vol. 20, No. 4, pp. 329-348.

Iskanius, P. and Kilpala, H. (2006) 'One step closer towards e-business - the implementation of a supporting ICT system', International Journal of Logistics: Research and Applications, Vol. 9, No. 3, pp. 283-293.

Iskanius, P., Helaskoski, H.S. and Page, T. (2009) 'A collaborative working tool for information systems integration and continuous improvement', International Journal of Business and Systems Research, Vol. 3, No. 2, pp. 202-215.

Johnston, D.L. (1998) 'Open networks, electronic commerce and the global information infrastructure', Computer Standards \& Interfaces, Vol. 20, pp. 95-99.

Kankaanpaa, T., Shamsuzzoha, A., Carneiro, L., Almeida, R., Helo, P., Fornasiero, R., Sena Ferreira, P. and Chiodi, A. (2010) 'Methodology for non-hierarchical collaborative networks for complex products manufacturing', Proceedings of ICE $201016^{\text {th }}$ Conference on Concurrent Enterprising, Lugano, Switzerland, pp. 21-23.

Lasser, R. (2011) 'Remote collaborative product development- a landmark survey', Industrial Marketing Management, Working paper, http://www.endeavourpds.com/pdf/Remote\%20Collaborative\%20PD.pdf, Retrieved on $23^{\text {rd }}$ October 2011.

Lee, S.M., Olson, D.L. and Trimi, S. (2012) 'Co-innovation: convergenomics, collaboration, and co-creation for organizational values', Management Decision, Vol. 50, No. 5, pp. $817-831$.

Lee, J., Chae, H. and Kim, C-H. (2009) 'Design of product ontology architecture for collaborative enterprises', Expert Systems with Applications, Vol. 36 No. 2, pp. 2300- 
2309.Levy, M. and P. Powell, P. (2000) 'Information systems strategy for small and medium sized enterprises: An organisational perspective', Journal of Strategic Information Systems, Vol. 9, pp. 63-84.

Li, M., Wang, J., Wong, Y.S. and Lee, K.S. (2005) 'A collaborative application portal for the mould industry', International Journal of Production Economics, Vol. 96, No. 2, pp. 233-247.

Li, J., Zhang, H. C., and Lin, Z. (2009) 'Asymmetric negotiation based collaborative product design for component reuse in disparate products', Computers \& Industrial Engineering, Vol. 57, No. 1, pp.80-90.

Malhotra, A. and Majchrzak, A. (2004) 'Enabling knowledge creation in far-flung teams: best practices for it support and knowledge sharing', Journal of Knowledge Management, Vol. 8, No. 4, pp. 75-88.

McDonough, E.F., Kahn, K.B., and Barczak, G. (2001) 'An investigation of the use of global, virtual, and collocated new product development teams', Journal of Product Innovation Management, Vol. 18, No. 2, pp. 110-120.

Ming, X.G., Yan, J.Q., Wang, X.H., Li, S.N., Lu, W.F., Peng, Q.J. and Ma, Y.S. (2008) 'Collaborative process planning and manufacturing in product lifecycle management', Computers in Industry, Vol. 59, No. 2-3, pp. 154-166.

Montoya, M.M., Massey, A.P., Hung, Y-T.C. and Crisp, C.B. (2009) 'Can you hear me now? Communication in virtual product development teams', The Journal of Product Innovation Management, Vol. 26, pp. 139-155.

Nami, M.R. and Tavangarian, D. (2007) 'Virtual organization: a new approach in IT', Proceedings of the 7th IEEE International Conference on Computer and Information Technology, Fukushima, Japan, October 16 - 19, pp. 93-98.

Nucciarelli, A. and Gastaldi, M. (2012) 'Collaboration in the airport business through the development of an IT platform', International Journal of Production Economics, Vol. 121 No. 2, pp. 562-573.

Panchal, J.H. and Fathianathan, M. (2008) 'Product realization in the age of mass collaboration', ASME 2008 International Design Engineering Technical Conferences and Computers and Information in Engineering Conference, Brooklyn, New York, USA, August 3-6, pp. 219-229.

Panetto, H., Jardim-Goncalves, R. and Molina, A. (2012) 'Enterprise integration and networking: theory and practice', Annual Reviews in Control, Vol. 36, No. 2, pp. 284290.

Park, K.H. and Favrel, J. (1999) 'Virtual enterprise - information system and networking solution', Computers \& Industrial Engineering, Vol. 37 No. 1-2, pp. 441-444.

Pawlak, A., Penkala, P., Jorgensen, H.D., Fraoe, P. and Sakowski, W. (2011) 'Collaborative engineering approach towards IP-based SoC design', http://www.designreuse.com/articles/18887/collaborative-ip-based-soc-design.html, Retrieved on $17^{\text {th }}$ October 2011.

Peng, D. X., Heim, G. R., \& Mallick, D. N. (2014) 'Collaborative product development: The effect of project complexity on the use of information technology tools and new product development practices' Production and Operations Management, Vol. 23, No. 8, pp. 1421-1438.

Phaithoonbuathong, P., Monfared, R., Kirkham, T. and West, A. (2010) 'Web services-based automation for the control and monitoring of production systems', International Journal of Computer Integrated Manufacturing, Vol. 23, No. 2, pp. 126-145. 
Pisano, G.P. and Verganti, R. (2008) 'Which kind of collaboration is right for you?', Harvard Business Review, http://hbr.org/2008/12/which-kind-of-collaboration-is-right-foryou/ar/1.

Pouly, M. and Huber, C. (2009) 'Collaborative networks: human aspects and corresponding IT support', Proceedings of the 13th International Conference on Computer Supported Cooperative Work in Design, CSCWD, Santiago, 22-24 April.

Rabelo, R.J., Gusmeroli, S., Arana, C. and Nagellen, T. (2006) 'The ECOLEAD ICT infrastructure for collaborative networked organizations. In L.M. Camarinha-Matos, H. Afsarmanesh \& M. Ollus (Eds.), Network-centric collaboration and supporting frameworks, International Federation for Information Processing (IFIP), Springer, New York, Vol. 224, pp. 451-460.

Rabelo, R.(2008) 'Advanced Collaborative Business ICT Infrastructures', In: Methods and Tools for Collaborative Networked Organizations, Springer, Heidelberg, pp. 337-370.

Rabelo, R.J., Gusmeroli, S., Nagellen, T. and Arana, C. (2009) 'An evolving plug-and play business infrastructure for networked organisations', International Journal of Information Technology and Management, Vol. 8, No. 3, pp. 260-282.

Ramanathan, U. And Gunasekaran, A. (2014) 'Supply chain collaboration: impact of success in long-term partnerships', International Journal of Production Economics, Vol. 147, pp. 252-259.

Ren, S.J., Hu, C., Ngai, E.W.T. and Zhou, M. (2014) 'An empirical analysis of interorganisational value co-creation in a supply chain: a process perspective', Production Planning \& Control: The Management of Operations, (In press).

Renner, K. (2002) 'The future of real time-Web-based services will enable real-time manufacturing ecosystems', MSI Magazine, June.

Romero, D. and Molina, A. (2014) 'Forward-green virtual enterprises and their breeding environments: sustainable manufacturing, logistics and consumption', In: CamarinhaMatos, L.M. and Afsarmanesh, H. (Eds.), Collaborative Systems for Smart Networked Environments, Springer Berlin, Heidelberg, Vol. 434, pp. 336-346.

Romero, D. and Molina, A. (2011) 'Collaborative networked organizations and customer communities: value co-creation and co-innovation in the networking era', Production Planning \& Control: The Management of Operations, Vol. 22, No. 5-6, pp. 447-472.

Schleimer, S.C. and Shulman, A.D. (2011) 'A comparison of new service versus new product development: configurations of collaborative intensity as predictors of performance', Journal of Product Innovation Management, Vol. 28, No. 4, pp. 521-535.

Shamsuzzoha, A., Kankaanpaa, T., Carneiro, L.M., Almeida, R., Chiodi, A. and Fornasiero, R. (2013) 'Dynamic and collaborative business networks in the fashion industry', International Journal of Computer Integrated Manufacturing, Vol. 26, No. 1-2, pp. 125-139.

Shamsuzzoha, A., Ferreira, F., Azevedo, A. Faria, J. and Helo, P. (2013) 'Business process monitoring and management in virtual enterprise through interactive user interface layer', In: Azevedo, A. (Eds), Advances in Sustainable and Competitive Manufacturing Systems, Springer International Publishing, Switzerland, pp. 451-464.

Shen, W. (2000) 'Web-based infrastructure for collaborative product design: an overview', Proceedings of the Sixth International Conference on Computer Supported Cooperative Work in Design, Hong Kong, China, pp. 239-244. 
Shen, W. and Wang, L. (2002) 'Web-based and agent-based approaches for collaborative product design: an overview', International Journal of Computer Applications in Technology, Vol. 16 No. 2-3, pp. 103-112.

Toye, G., Cutkosky, M.R., Leifer, L.J., Tanenbaum, J.M. and Glicksman, J. (1993) 'SHARE: a methodology and environment for collaborative product development', Technical Report CDR-TR no.19930507, Center for Design Research, pp. 28-36.

Valilai, O.F. and Houshmand, M. (2013) 'A collaborative and integrated platform to support distributed manufacturing system using a service-oriented approach based on cloud computing paradigm', Robotics and Computer-Integrated Manufacturing, Vol. 29, No. 1 , pp. 110-127.

Verdecho, M-J., Alfaro-Saiz, J-J., Rodriguez, R.R. and Ortiz-Bas, A. (2012) 'A multi-criteria approach for managing inter-enterprise collaborative relationships', Omega, Vol. 40 No. 3, pp. 249-263.

Wang, H.W. and Zhang, H.M. (2008) 'An integrated and collaborative approach for complex product development in distributed heterogeneous environment', International Journal of Production Research, Vol. 46 No. 9, pp. 2345-2361.

Wortmann and Szirbik, N. (2005) 'ICT issues among collaborative enterprises: from rigid to adaptive agent-based technologies', Production Planning and Control: The Management of Operations, Vol. 12, No. 5, pp. 452-465.

$\mathrm{Wu}$, J. (2012) 'Technological collaboration in product innovation: the role of market competition and sectoral technological intensity', Research Policy, Vol. 41, No. 2, pp. 489-496.

Young, J. (2008) 'Trust in virtual organisations: a synthesis of the literature', International Journal of Networking and Virtual Organisations, Vol. 5, No. 3-4, pp. 244-258. 